

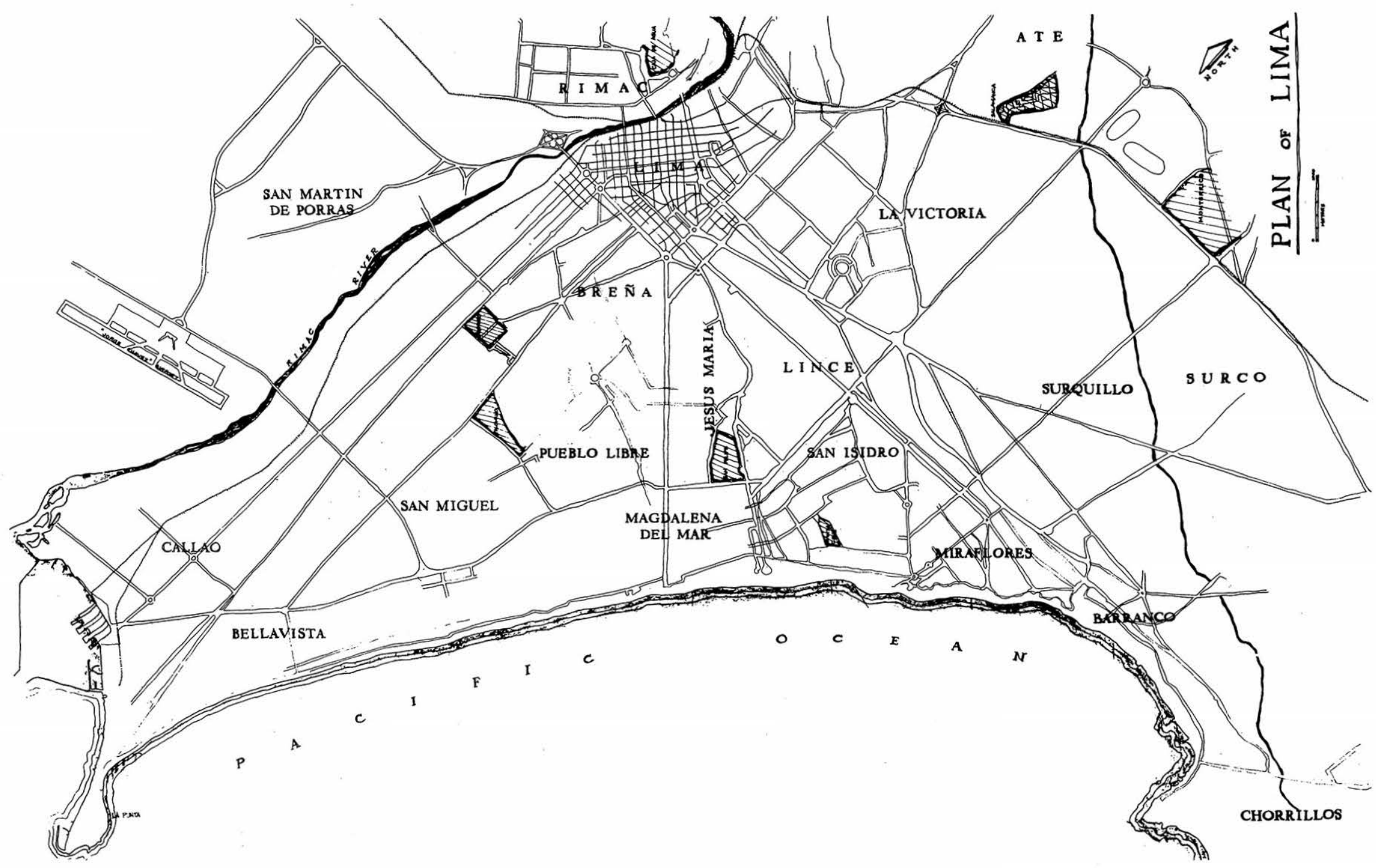




\section{LIMA, PERU \\ A Study of Housing in an Arid Coastal Region}

prepared by

ROBERT D. TROY, AIA

DEPARTMENT OF ARCHITECTURE

TEXAS TECHNOLOGICAL COLLEGE

sponsored by

THE AMERICAN INSTITUTE OF ARCHITECTS

and

THE TEXAS ARCHITECTURAL FOUNDATION

$1967-1968$

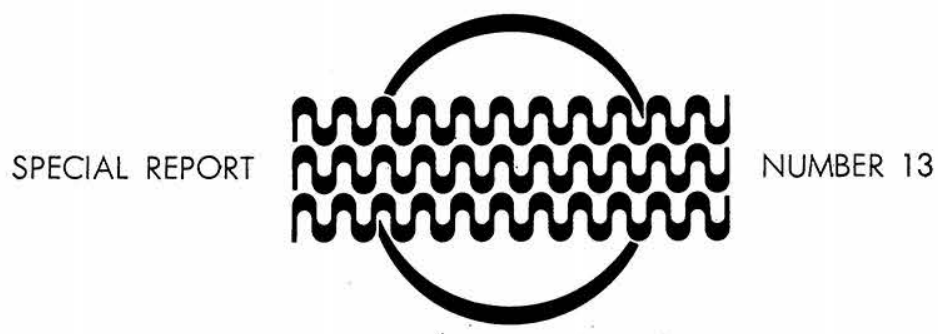

INTERNATIONAL CENTER FOR ARID AND SEMI-ARID LAND STUDIES 
Copyright, 1969

by

ROBERT D. TROY

Lubbock, Texas

Printed By

THE TEXAS TECH PRESS

Texas Technological College

Lubbock, Texas

U.S.A. 


\section{PREFACE}

With the establishment of the International Center for Arid and Semi-Arid Land Studies (ICASALS) at Texas Technological College, the university embarked upon a significant role in education and public service. Its program of "documentation and dissemination of knorvledge in the fullest sense of the word, about arid and semi-arid lands, their peoples and their problems" suggests an avenue for contribution from the Department of Architecture. Much of our study and work is concerned with architecture of other lands, both historical and modern.

The name "Perú" is most often thought of in connection with the glories of the Pre-Incan and Incan civilizations, and perhaps even with the Spanish colonization of the New World. What of the Perú of today? Is the greatness of Perús past civilizations its only significant contribution to the development of man? I think not.

Previous trips to Perú in 1962 and 1965 gave me reason in 1967 to believe that I, as an architect, could contribute a valid documentation of certain aspects of that nation's housing problems to the ICASALS program. In particular, I felt that Lima, because of its location in an arid region, would present a good case study for the documentation. Therefore, this publication should be considered as an analysis of architectural solutions to extreme housing problems in the Peruvian capital. It should not be considered in terms of a comparison between architectural construction in Perú and the United States. Perús problems in this area are totally different from those existing in the temperate zone of the United States but quite similar to those in the arid southwestern areas. The climate is milder in Lima.

I am very grateful to the American Institute of Architects, which helped to fund this project with a Langley Scholarship, and also to the Texas Architectural Foundation, which made available a supplemental grant from the M. D. Anderson Fund. I am especially grateful to the International Center for Arid and Semi-Arid Land Studies for financial assistance in the publication of this manuscript. In addition, I would like to express my appreciation to Mr. Nolan E. Barrick, Chairman of the Department of Architecture, for his encouragement in initiating this project; to Architect Guillermo Vidaud and María Elena de la Vega de Vidaud for their constant encouragement and help; to my family for additional assistance; and particularly to my wife Nora, whose assistance and translations helped to make this work a reality.

Robert D. Troy, AIA 


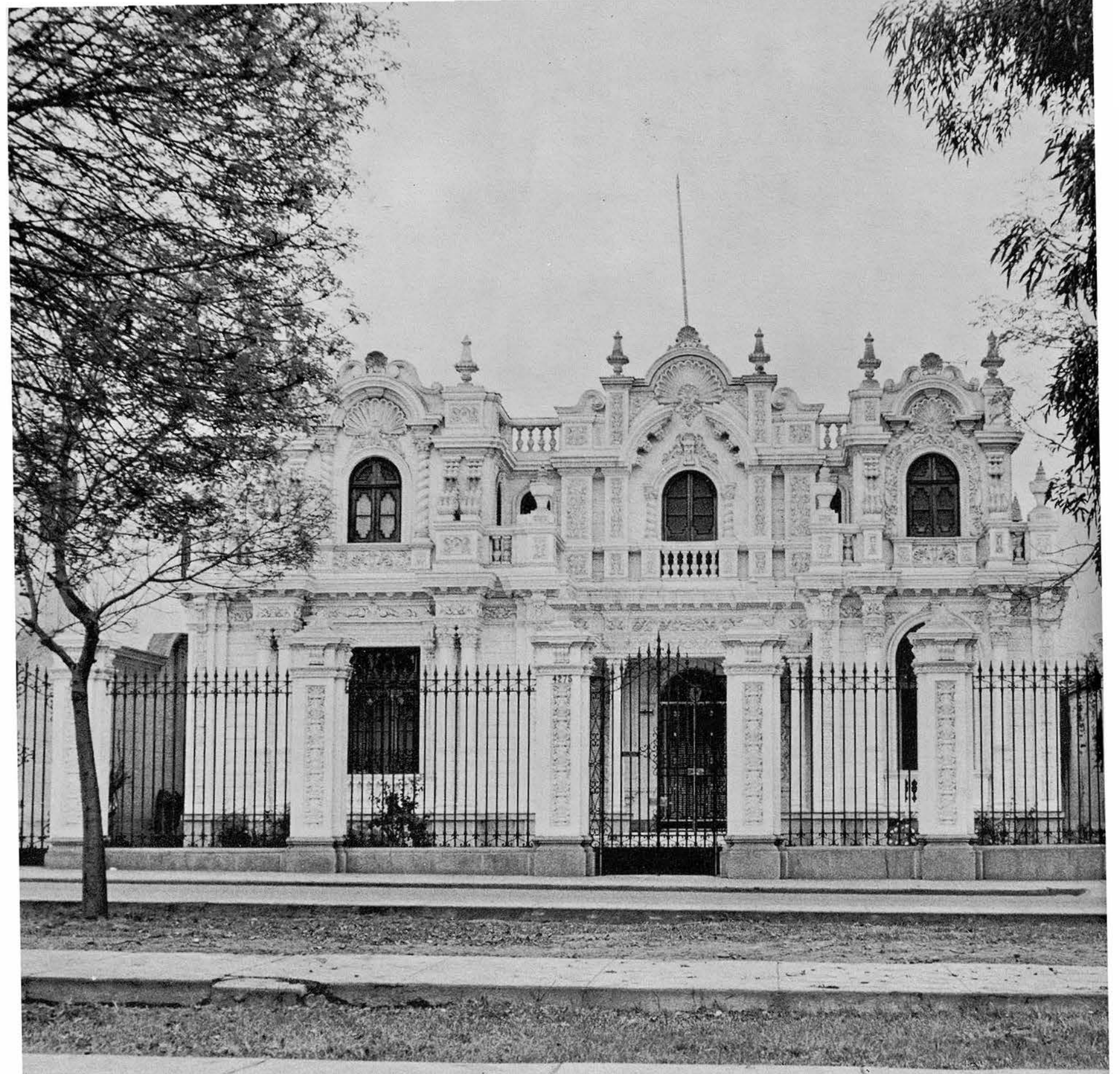




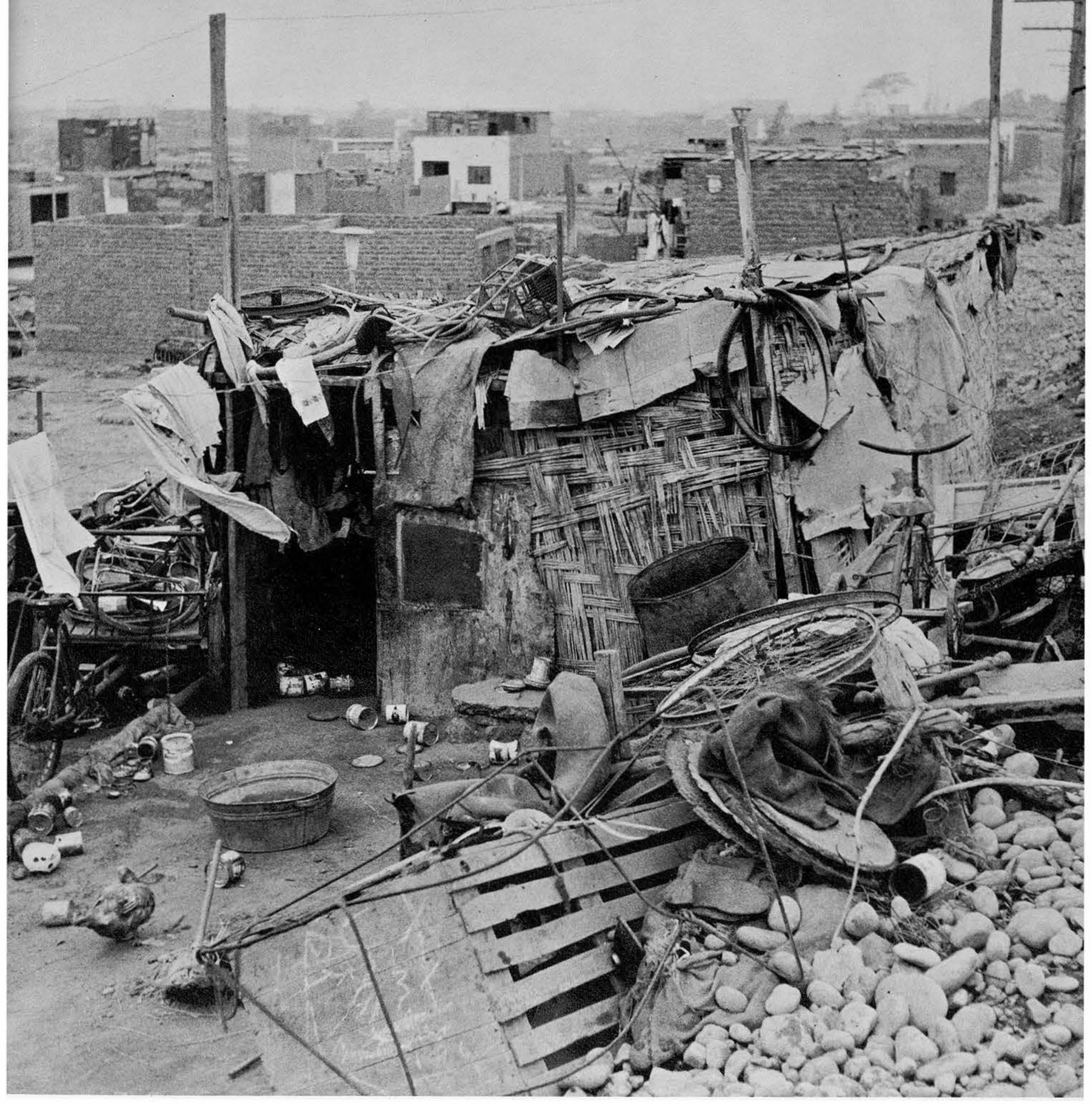

ity of Contrasts (2)

rol of people as well as in gold and silver. Early settlers is land discovered that the Indian people, whose empire stretched from the modern day countries of Colombia Ecuador to the north, Chile to south, Bolivia and Brazil he east and halted on the west by the Pacific Ocean, lost without the leadership of their "Lord Inca." The ins' plight was compounded by the type of social system which they emerged. The communal system of life to $h$ they were accustomed provided for an organized type ving where no man went hungry and every man worked. "Lord Inca" was supreme ruler-God on earth. los colonizadores pronto se dieron cuenta de que igualmente podían contar como riquezas la posesión de tierras y el control de las multitudes humanas, tanto como la posesión de oro y plata. Estos primeros colonizadores descubrieron que los Indios, cuyo imperio había abarcado desde los paises actuales de Colombia y Ecuador al norte, Chile al sur, Bolivia y Brazil al este y terminando con el Oceano Pacífico al oeste, estaban perdidos sin la administración de su Inca. El problema de los Indios se complicaba por el tipo de sistema social del cual ellos emergían. El sistema comunal de vida al cual ellos estaban acostumbrados les proporcionaba un tipo 


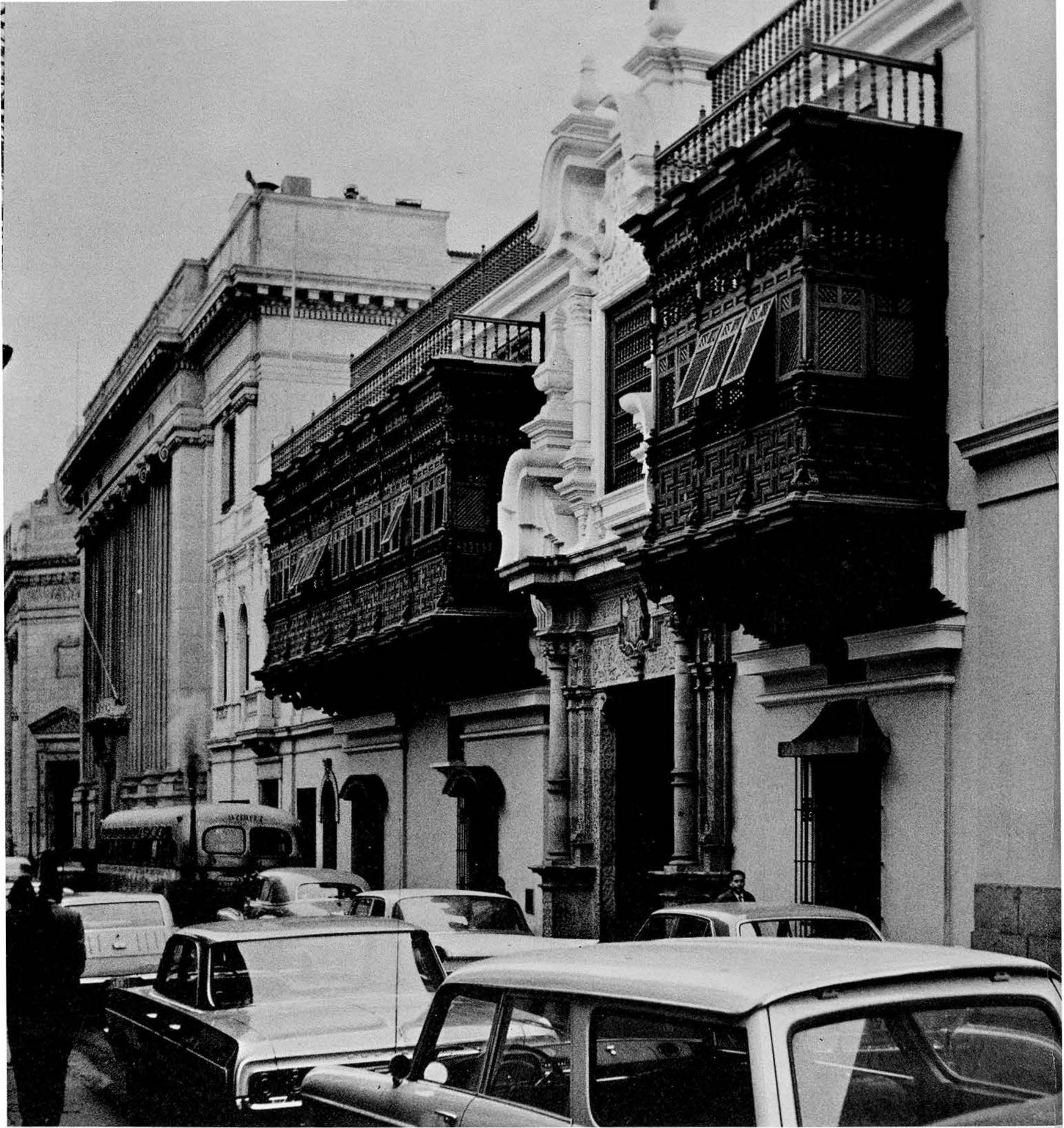

Palacio Torre Tagle (3)

Leaderless, the Incan people soon found themselves living in a feudalist system, with the conquering Spaniard their newly acquired lord. It remained that way for a little less than 300 years while under the reins of the Spanish government. After independence was gained from Spain under the liberators Simon Bolivar and José de San Martin (1821), the Indians' plight did not improve significantly. They still belonged basically to the land,. dependent upon the feudal lord for much that was theirs during a lifetime. The church from Rome did very little toward helping the Indians progress. Their religious temples were destroyed and upon de vida organizado donde nadie padecía de hambre y tod trabajaban. El Inca era el supremo gobernante-un dios e la tierra.

Sin su jefe, el pueblo Inca pronto se encontró victim de un sistema feudal teniendo al conquistador Español con su nuevo jefe. Así permaneció poco menos de 300 aî́ bajo el dominio del gobierno Español. Después de ind pendizarse de España con la ayuda de los libertadores Sim Bolivar y José de San Martín (1821), el problema del in no cambió significativamente. Aún permanecieron atal a la tierra, dependiendo del señor feudal para casi todo 


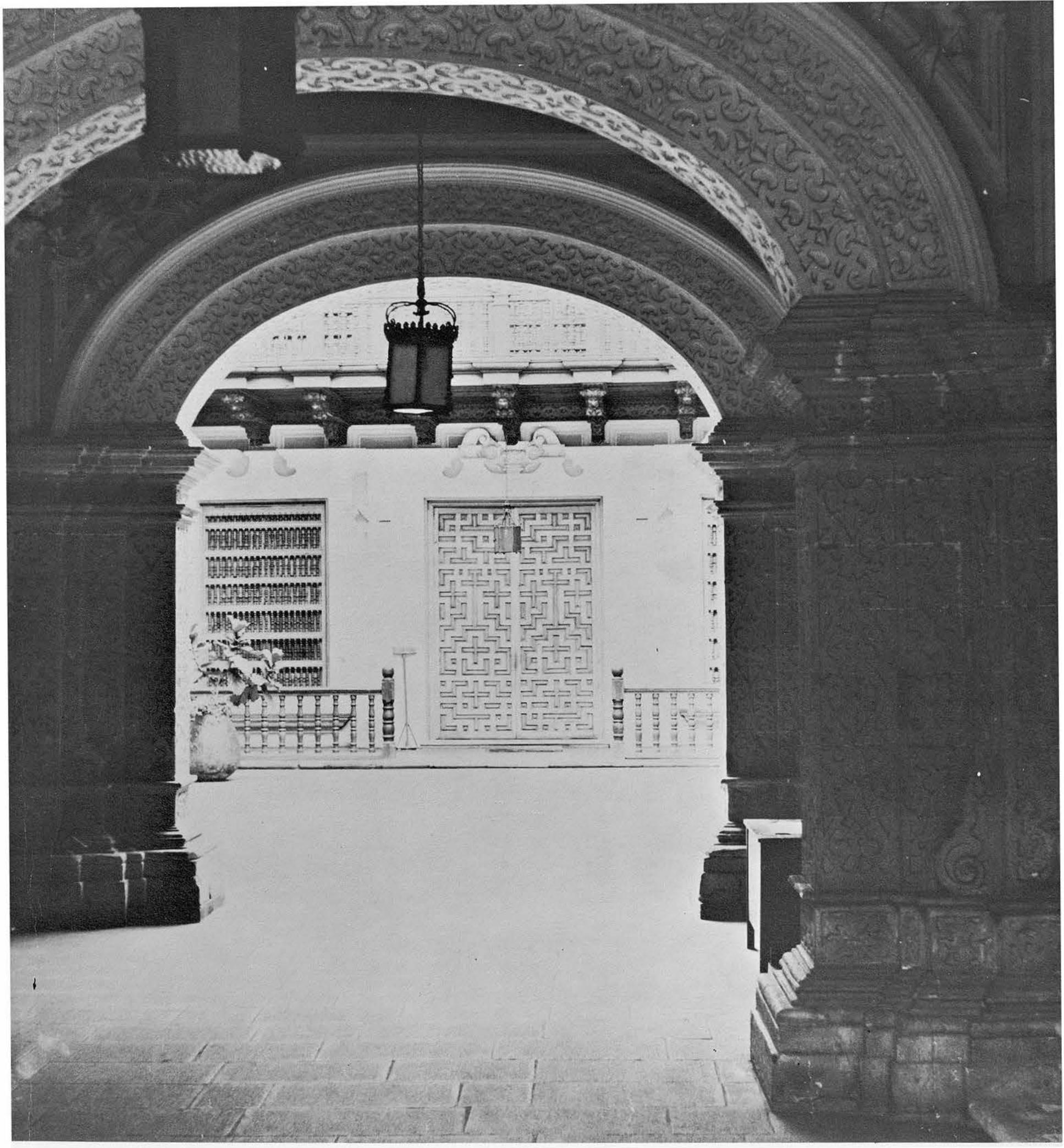

\section{llacio Torre Tagle (4)}

: foundations of these pagan temples were built churches which Spanish and Latin were spoken-not Quechua the other Indian languages.

As a center for government, and because of its near$s$ to the modern day port of Callao, Lima flourished as ultural center in the New World. Fine palaces were built families in the center of the city. (See photographs 3, 4, and 6-Palacio de Torre Tagle.) These served many poses other than as strictly living quarters. They were ats of activity for business, as well as residences. Colonial dential architecture reflected the Spanish-Moorish in- que necesitaron durante sus vidas. La iglesia de Roma hizo poco para ayudar al progreso del Indio. Sus templos fueron destruídos y sobre los cimientos de estos templos paganos se construyeron iglesias en las cuales se hablaban Español y Latin-no el Quechua ni los otros idiomas indígenos.

Como centro de gobierno virreynal y por su cercanía al puerto actual del Callao, Lima floreció como un centro cultural en el Nuevo Mundo. Bellos palacios fueron construídos por familias de importancia en el centro de la ciudad. (Ver fotografías 3, 4, 5 y 6-Palacio de Torre Tagle.) Estos palacios servian para muchos fines, no solo como 


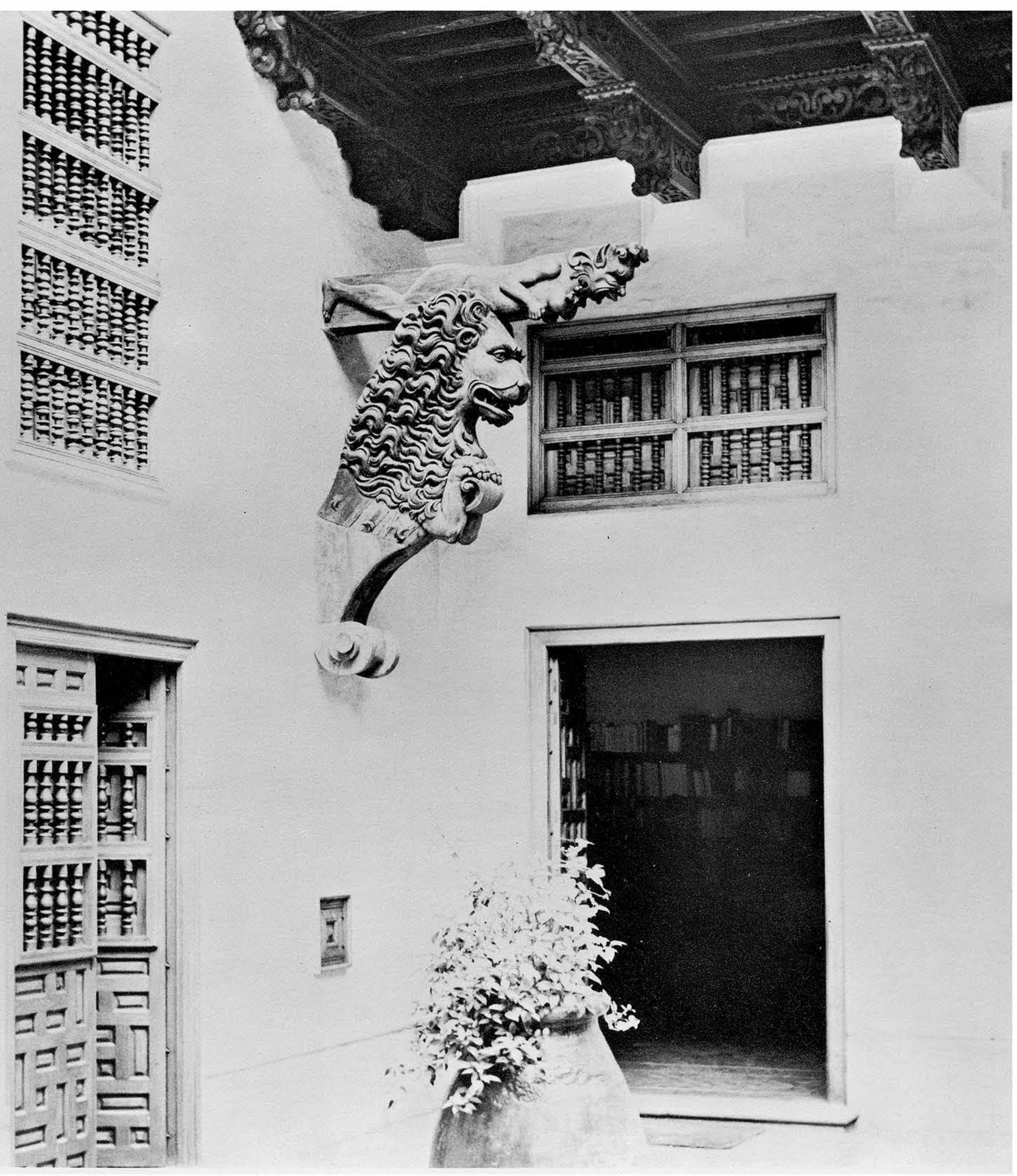

\section{lacio Torre Tagle (6)}

$\mathrm{d}$ bearing walls were built of "adobe" (sun dried mud :ks) and the lesser walls (or non load bearing) were de with cane, mud and "estera" (woven cane). (See the 1cture of the wall of the old University of San Marcos, rograph 17, and the open air shop at Caja de Agua, phoraph 18.) Occasionally brick was used in the walls but primary usage was for the construction of floors. :ook the form of either large squares or smaller rectangupieces. Brick tile was also used in stairway construcI contained at the edge by a strip of wood. Wood rarely used in actual construction except for the decora- de la importancia de los dueños y estaba rodeado de habitaciones. Se entraba a la residencia atravéz del zaguán, diseñado de tal forma que se podia ver la calle desde el primer patio. Las paredes de carga se construían de adobe y las restantes se hacían con caña, barro y estera (ver la estructura de la pared de la antigua Universidad de San Marcos, fotografía No. 17 y la tienda al aire libre en Caja de Agua, fotografía No. 18.) Aveces se usaban lozas de barro en las paredes pero su uso principal era en la construcción de pisos tomando forma de cuadrados grandes o pedazos mas pequeños rectangulares. Las lozas tambien se utilizaban en 


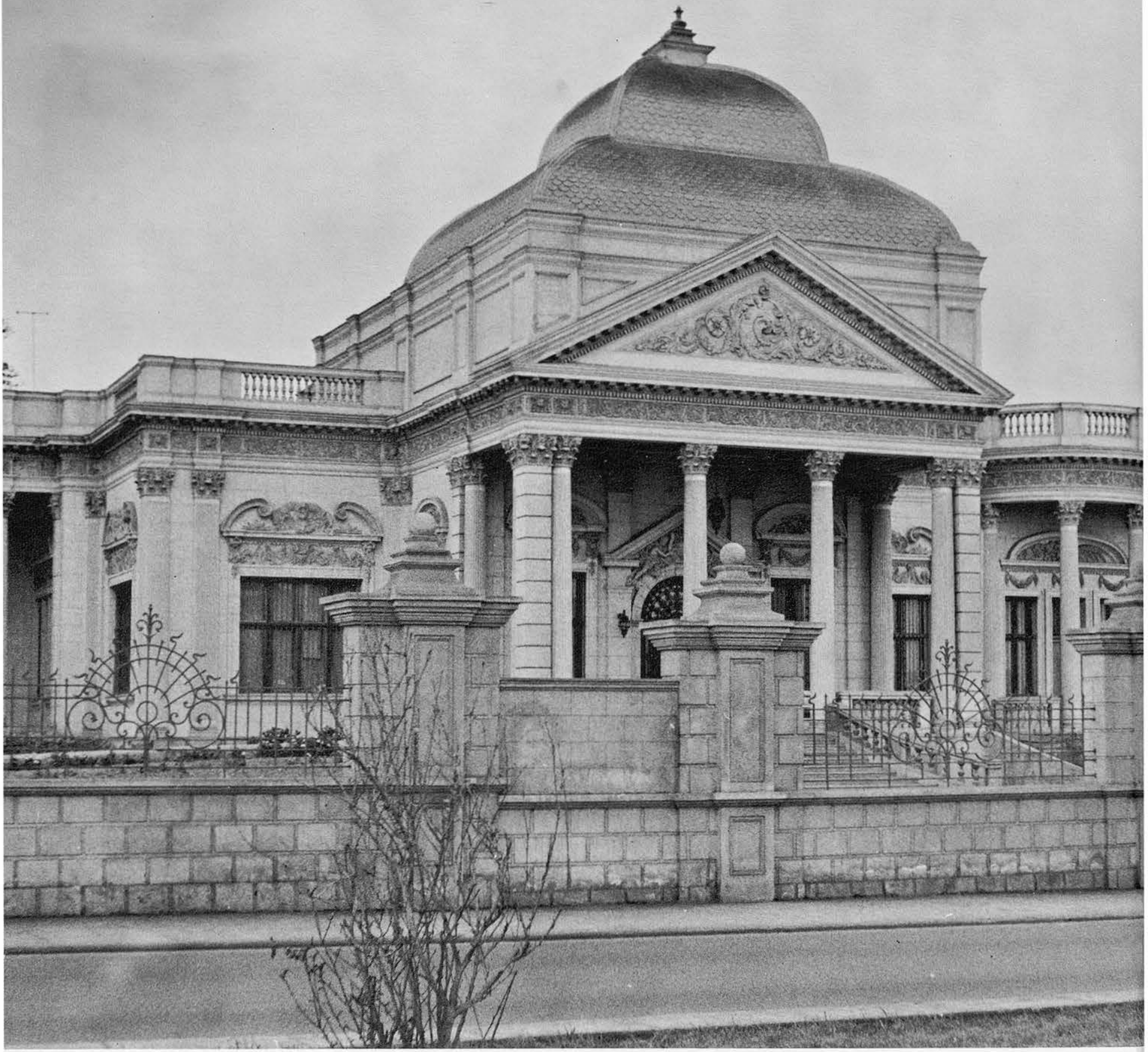

\section{Residence, Miraflores (7)}

tive balconies, beams and doors. The roofs consisted basically of large beams supporting a variously layered network of thin cane, over which mud and bricks were laid, finished off by layers of woven cane covered with mud ("quincha") and finally whitewashed. Due to the temperate climate and the absence of rain in Lima, pitched roofs were not common. The exterior of the colonial residence was usually arranged asymetrically, however, in the case of public buildings or palaces, the facade could be symetrically arranged. All doors opening on the street were large, made of solid wood, and usually adorned with heavy brass knockers. Spikes were used la construcción de escaleras que se sostenían en los b con piezas de madera. La madera era escásamente usad la construcción con la excepción de los balcones decoral vigas y puertas. Los techos consistían básicamente de grandes que soportaban a una red de caña delgada la cu cubría con barro o ladrillos terminándose con capas de $\epsilon$ cubiertas con barro (quincha) y lechada (o pintura d y agua.) Debido a la temperatura templada y la falı lluvia, existían pocos techos en declive. El exterior , residencia colonial era generalmente asimétrico, aunqu los casos de edificios públicos o palacios la fachada podi 


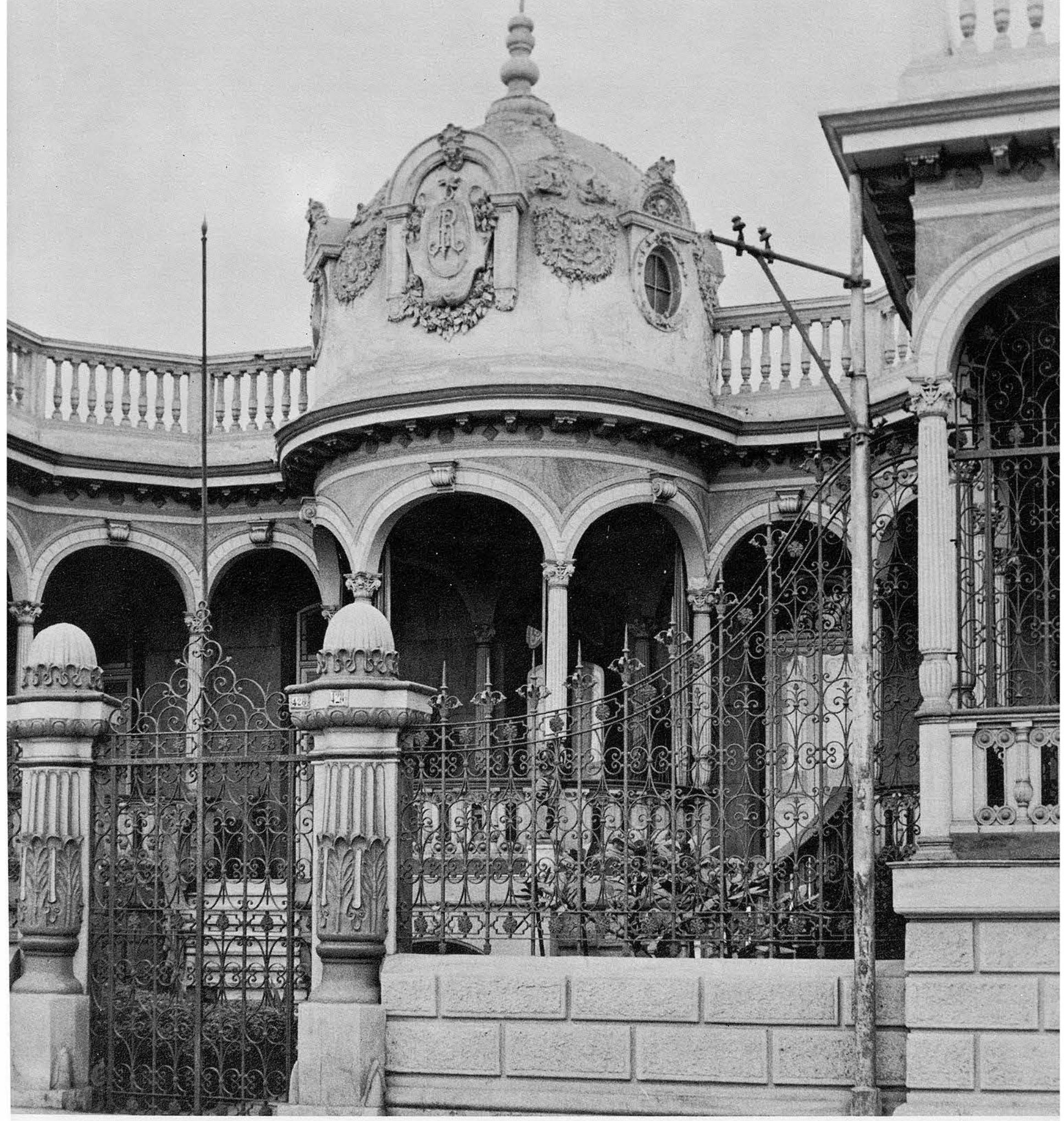

ssidence, Barranco (8)

fasten the doors together. One outstanding feature of the onial residential-palace was the enclosed wood balcony orated in the eastern tradition which projected above : street. Later in the colonial period balconies were also istructed of iron.

Following the independence of Perú from Spain in 21, Peruvian residential, as well as other, architecture, s characterized by a rejection of traditional (Spanish inenced) architecture. An acceptance of the French and lian as models was practiced. Creole or "mestizo" techue adopted a Classical Revival approach (see photo- asimétrica. Todas las puertas que abrían hacía la calle eran grandes y hechas de madera sólida, generalmente adornadas con grandes tocadores de bronce y se fijaban con grandes clavos. Un aspecto sobresaliente de la residencia-palacio colonial era el balcón cerrado de madera decorado al estilo oriental que proyectaba sobre la calle. Mas adelante durante el periodo colonial se construyeron balcones de hierro.

Despues de independizárse el Perú de España en 182.1, la arquitectura residencial Peruana, tanto como las otras manifestaciones arquitectónicas, se caracterizó por un desdén de todo lo tradicional (Español). Se aceptó lo Francés 


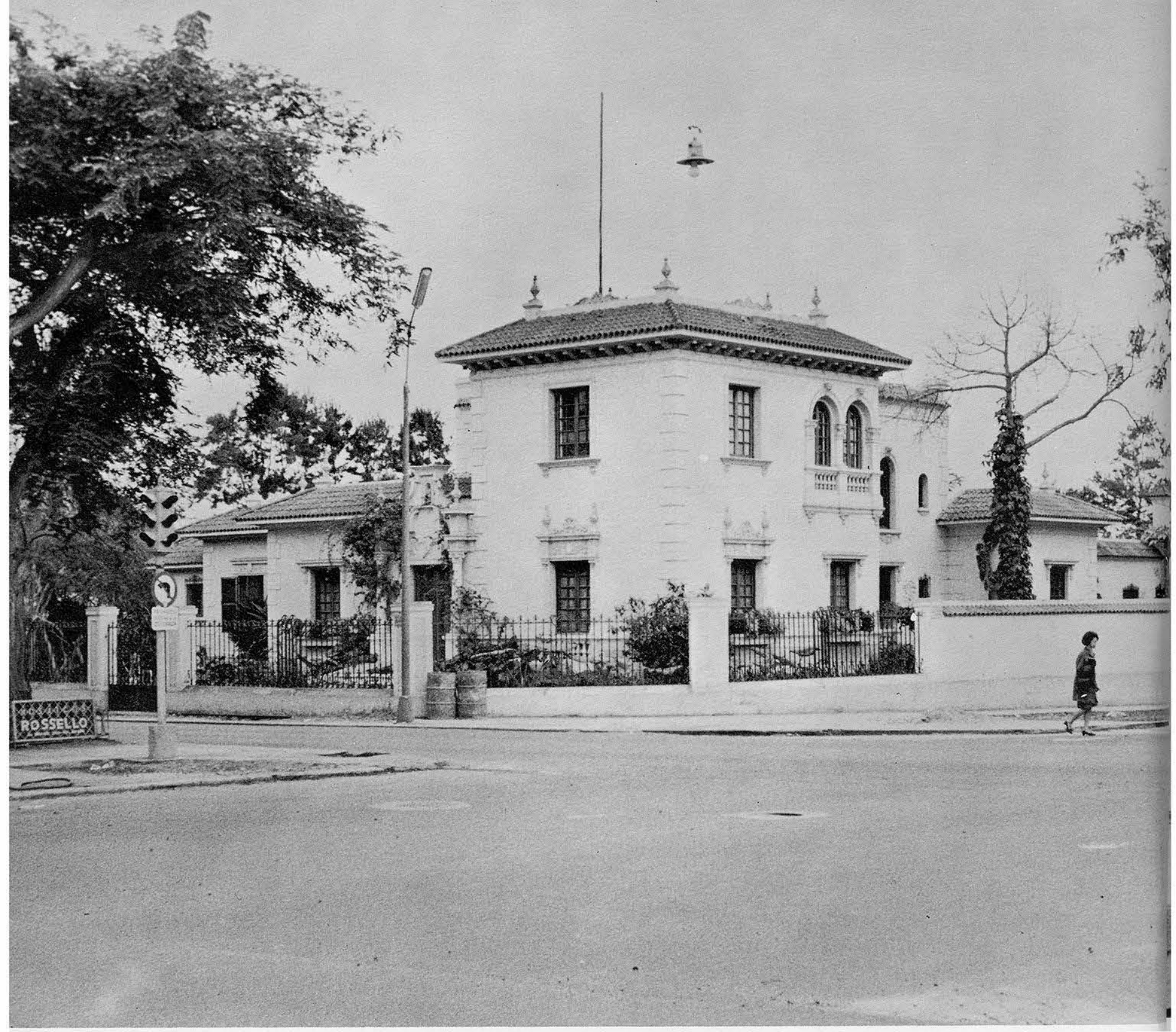

Residence, Lima (11)

from Japan since only one steel factory exists in Perú.) Some stonework is also evident in Lima, although the quality of that seen today does not measure up to the quality of the past.

- 20. Perhaps the greatest modern day housing problem in Lima is how to replace the tremendous slums-known as "barriadas," that are choking the city. Approximately 250,000 people of Lima's over two million population are forced to live in "barriadas." The "barriadas" are first of all a result of economic deprivation. Secondly, they reflect the existence of poorly educated and trained people. And thirdly, they exist ornamentación), hormigón armado, y muy poco $i$ (importado básicamente del Japón ya que existe solo: fábrica de acero en el Perú.) Aún existe en Lima alø trabajo en piedra aunque este no es de la calidad de " de tiempos pasados.

Quizá el problema más grande de la vivienda de en Lima es el como reemplazar las barriadas que P ahogando a la ciudad. Aproximadamente 250,000 pert de la población de mas de dos millones de Lima se f $^{t}$ entran forzados a vivir en las barriadas. Las barriada! principalmente el resultado de la privación econót 


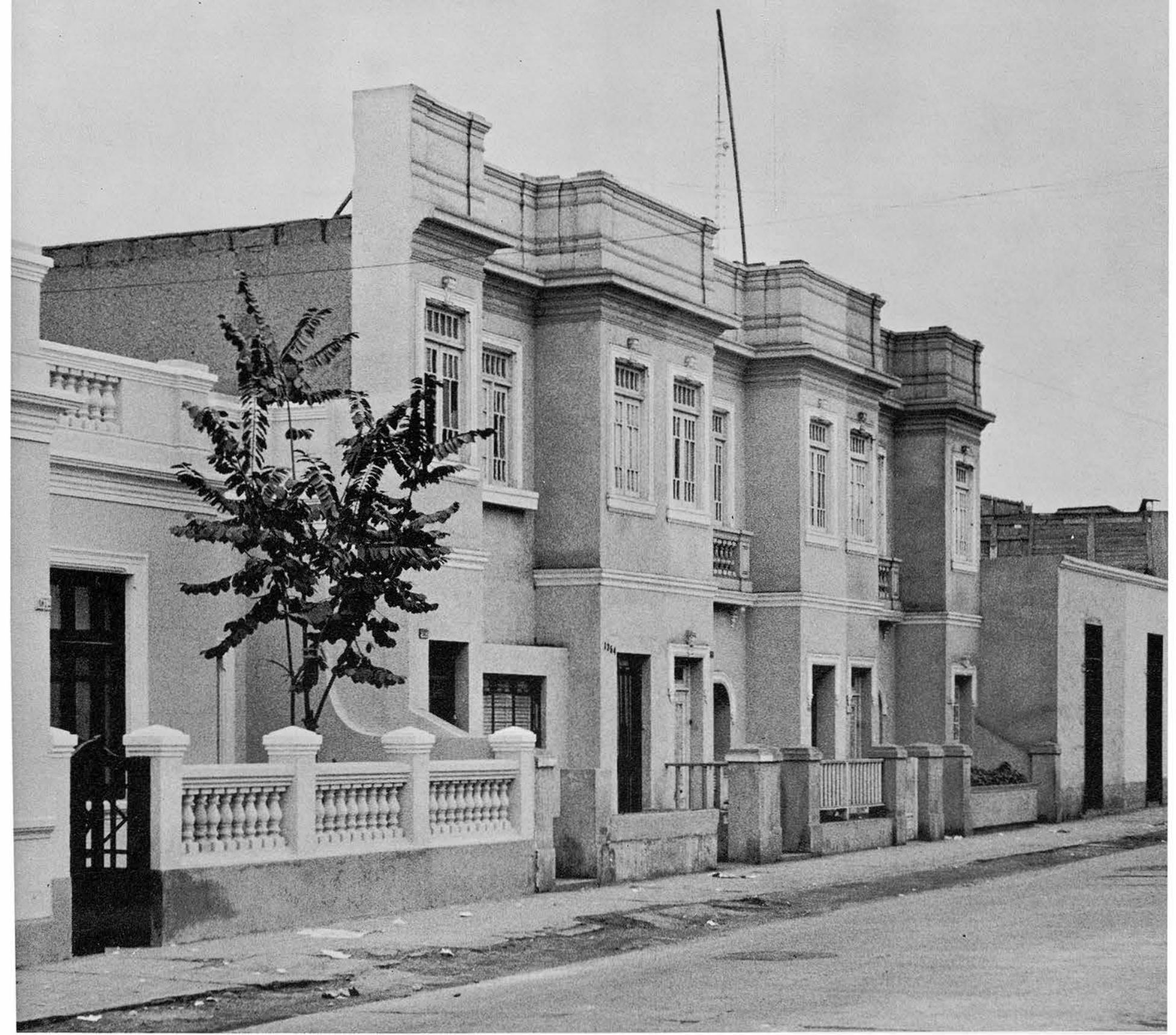

sidence, Lima (12)

ause of poor city planning in past years. (See photophs 21, 22, 23, 24, 25 and 26.) It must be said, though, partial defense of the existing situation, that some of "barriadas" came about because of sheer numbers of peoestablishing a housing area literally overnight; in other rds, by their bodily taking over a piece of land and squat$\mathrm{g}$, these people forced the government to lose control. No would dare try to move those masses of people after $y$ had once established a place to live. The government ! police force have found it nearly impossible to do anyig about the situation, an exception to this rule being
Reflejan al mismo tiempo la existencia de personas de escasa educación y sin entrenamiento alguno para ganarse la vida. $\mathrm{Y}$, por último, existen por la falta de planeamiento de años pasados. (Ver fotografías 21, 22, 23, 24, 25 y 26.) No obstante, se debe decir, en defensa parcial de la situación existente, que algunas de las barriadas llegaron a existir sencillamente porque vastos grupos de personas se establecieron del dia a la noche, usurpando una porción de tierra y forzando al gobierno a perder el control de la misma. Nadie se atrevería a forzar a estas masas humanas a mudarse después de haberse establecido. El gobierno y la policía han 


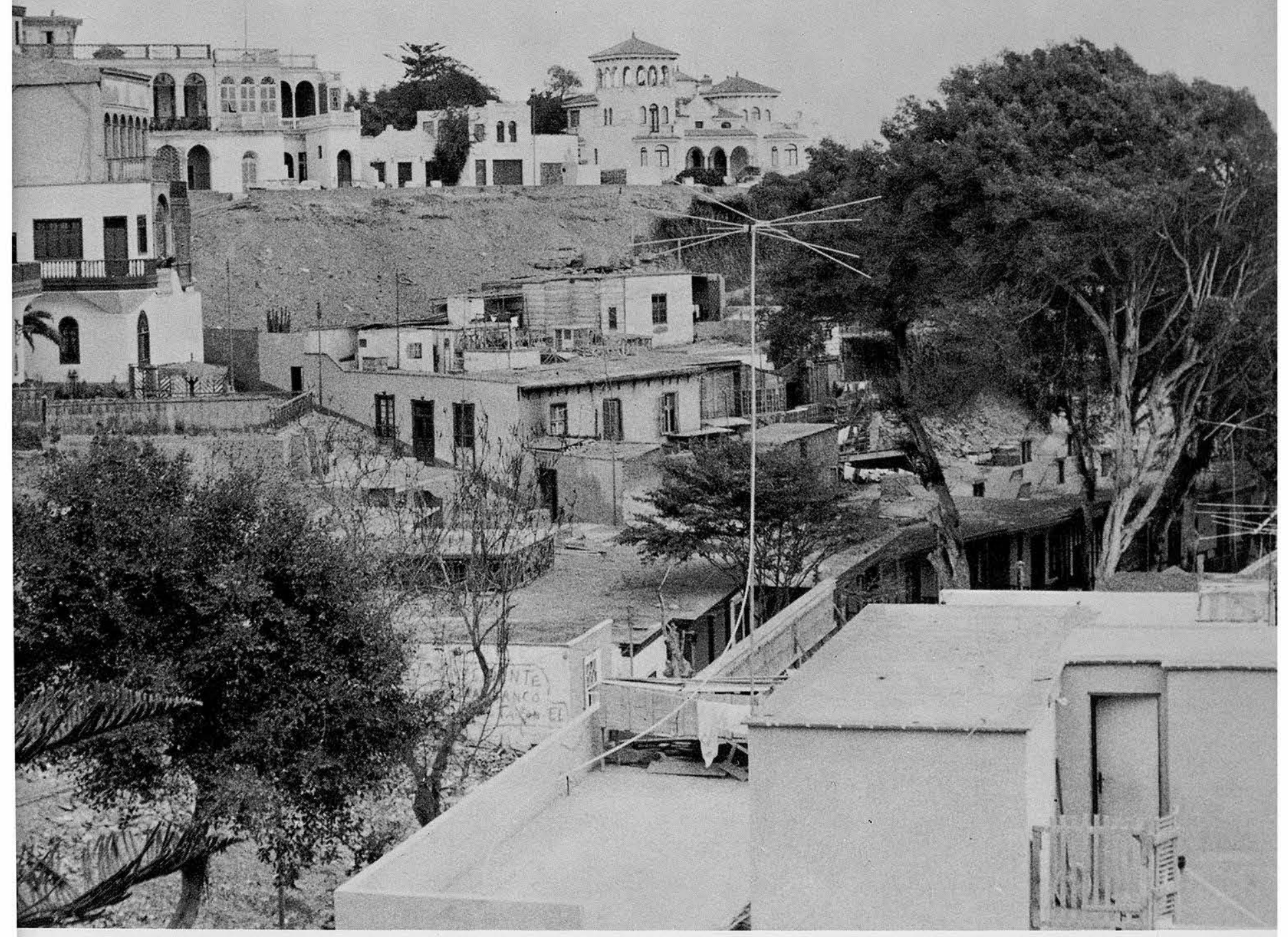

using, Barranco (14)

ity provided only in this large city. (Lima acts as a gnet to Peruvians. Most Peruvians feel that if any work sts in the nation, it will be in or around this capital city.) $\geq$ result of the decree is really unimaginable. Haphazard istruction techniques employed by the squatters in buildtheir dwellings are evident from the photographs. No e of city planning exists within the "barriadas." An overwded type of living, with neither public nor privately vided sanitary facilities, has contributed to the utter $h$ and stench within the "barriadas." No electricity is proed in most cases. primera vez en sus vidas se encontraban expuestos a la oportunidad económica existente en esta gran ciudad. (Lima es como un imán para los Peruanos. La mayoría de ellos piensan que si en algún lugar del Perú ha de haber trabajo, tiene que ser en esta ciudad, la capital.) El resultado del decreto es inimaginable. Las técnicas de construcción casuales y sin cuidado se pueden apreciar por medio de las fotografías. Ningun tipo de planeamiento existe dentro de las barriadas. Un tipo de vida congestionado sin facilidades sanitarias públicas ni privadas ha contribuído a una suciedad 


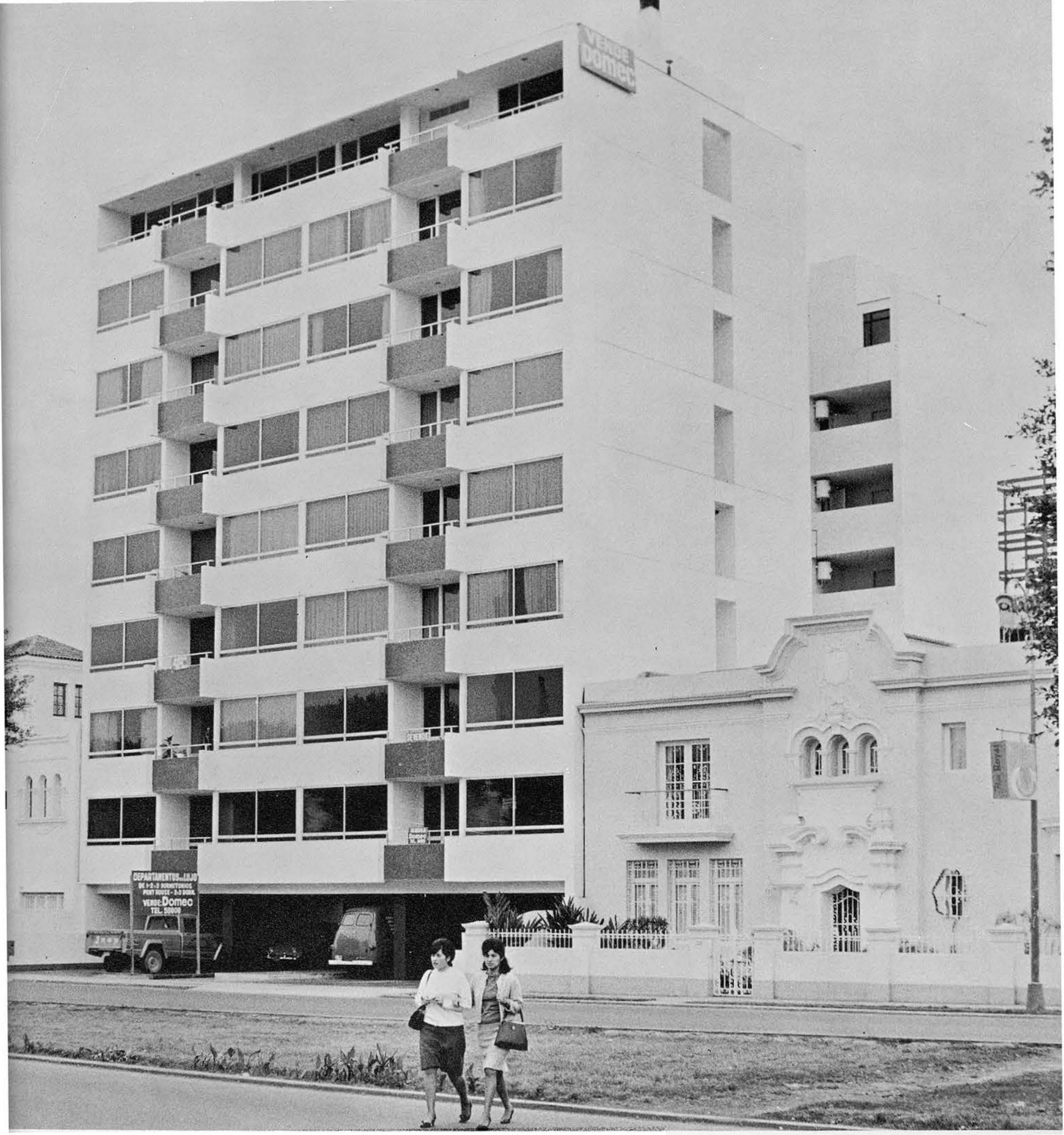

artment House, Lima (16)

ght be felt by leaving the mountains. His yearly income, iverted to dollars, is approximately $\$ 120.00$. One insting comment about the "barriadas" should be made. merous United States Peace Corps volunteers are living these communities to try in some small way to help ter the daily lives of the inhabitants.

Housing proposals by the Peruvian government to solve ir problems are not new, but the current administration, ler the leadership of President Fernando Belaúnde Terry $\therefore$ of Architecture, University of Texas, 1935) has initiated aassive program that is helping to provide much needed de vida y las oportunidades que se le proporcionan al hombre común de la barriada en la ciudad de Lima no le hace extrañar su tierra serrana. Su entrada al año convertida en dólares es apróximadamente $\$ 120.00$. See debe hacer un comentario acerca de las barriadas. En estas comunidades hoy en dia se encuentran muchos voluntarios del Cuerpo de Paz que en alguna forma tratan diariamente de ayudar a aliviar las condiciones de vida.

Proposiciones para resolver el problema de la vivienda por parte del gobierno Peruano no son algo nuevo, pero la administración presente, bajo el Presidente Fernando 


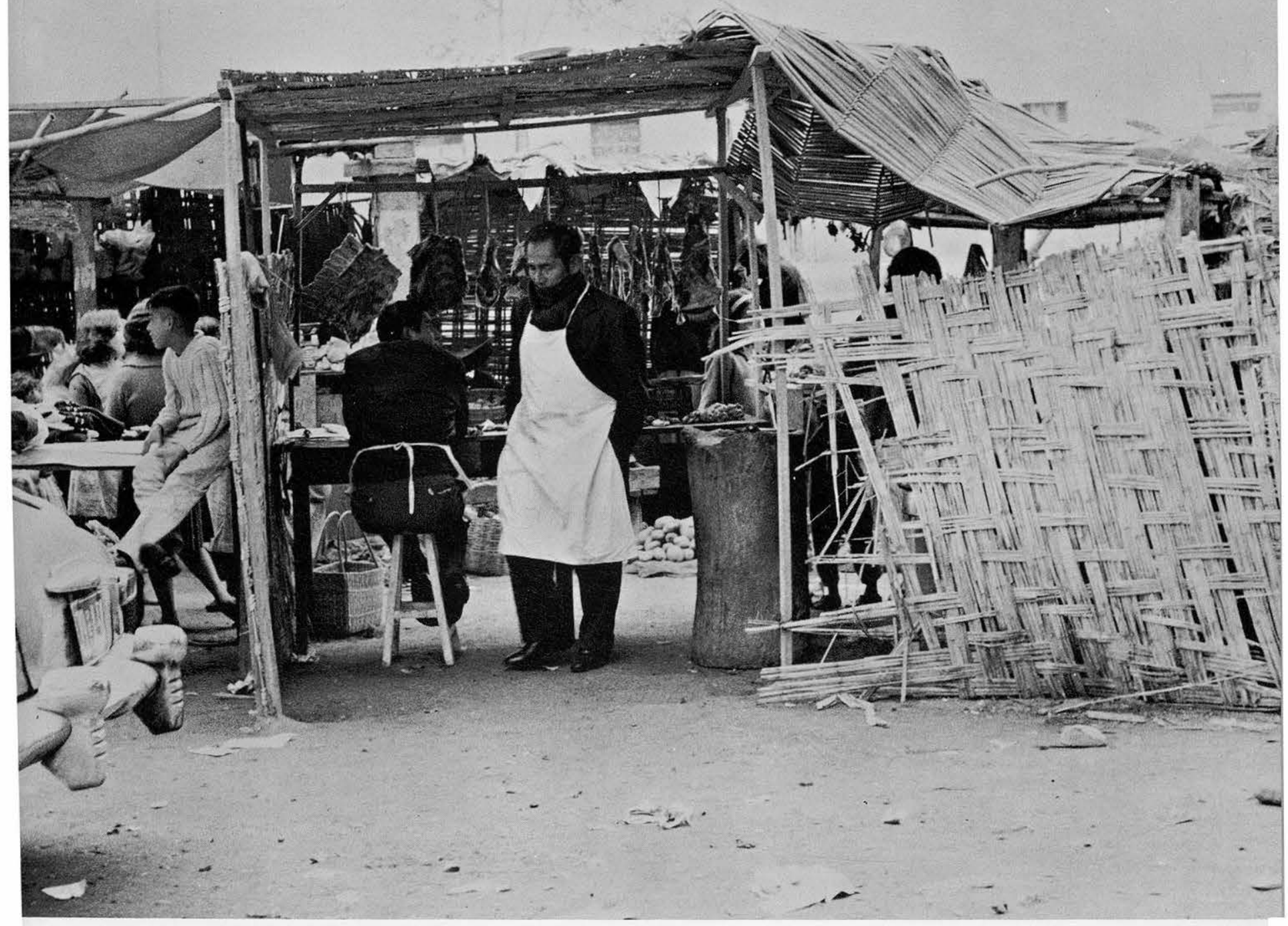

\section{de Agua, Lima (18)}

that flows through the city, was destroyed by a The government grasped the opportunity created by e to reestablish the community in a better designed and ally improved environment. They built Caja de (see photographs 27, 28, 29 and 30,) which conIf 1,596 houses that are sold to the occupants. Fiig for this, and most of the other housing projects President Belaúnde's administration, comes from inional loans. The prospective home owner can arrange ing for house and land through newly established $s$ and loan agencies, and mutual funds. The project actualmente dá conferencias en la Universidad de Harvard.)

Hace varios años una de las barriadas cerca del Río Rimac que penetra en la Ciudad de Lima fué destrozada por una inundación. El gobierno tomó esta oportunidad para reestablecer esta comunidad en un ambiente mejor diseñado y de mejores condiciones físicas. Se construyó Caja de Agua (ver fotografías $27,28,29$ y 30 ) que consiste de 1,596 casas vendidas a sus residentes. El financiamiento de este proyecto, asi como la mayoría de los otros proyectos de viviendas ejecutados durante el término del Presidente Belaúnde, vienen de préstamos internacionales. El futuro 



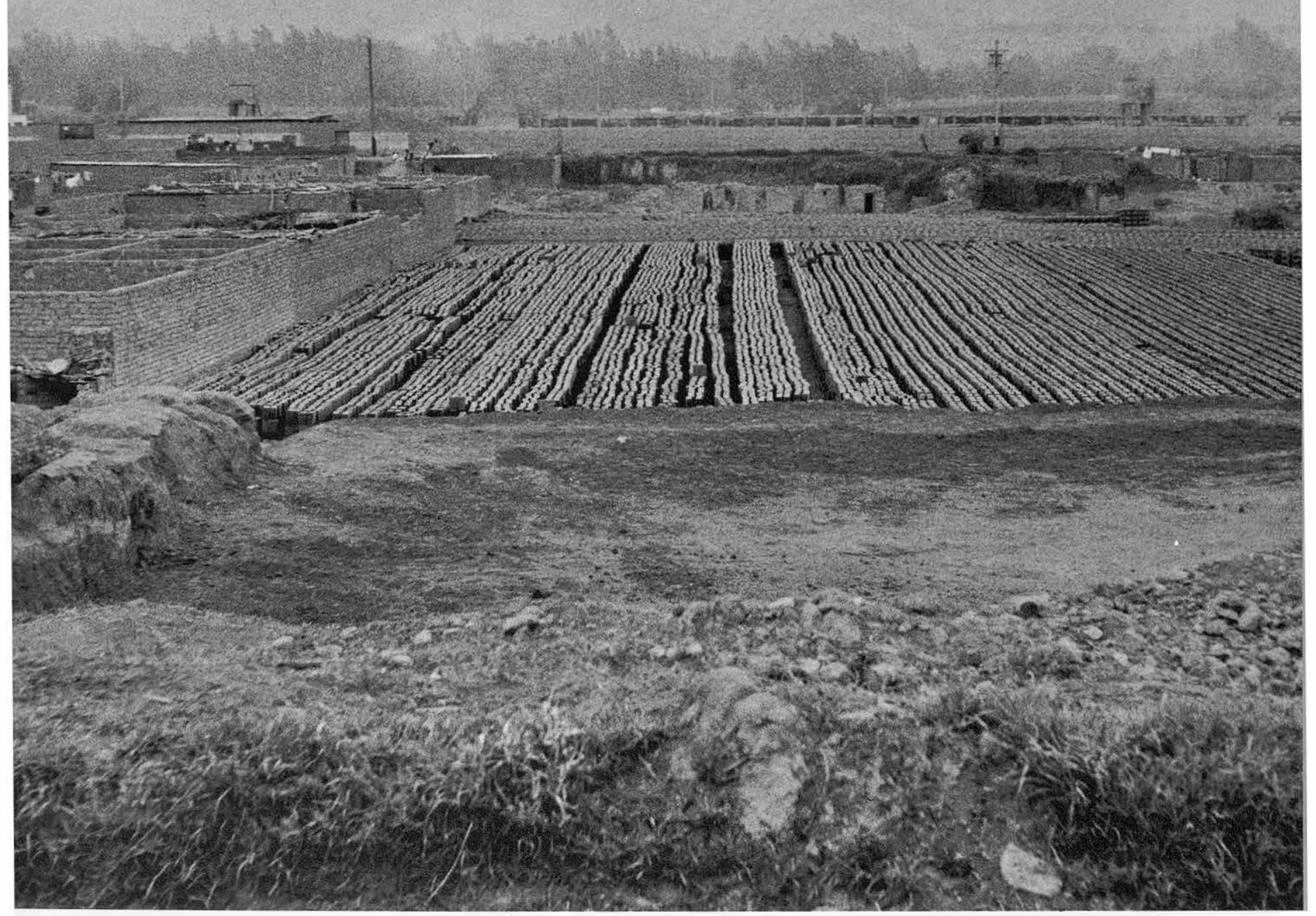

\section{Factory, Santa Clara (20)}

onstruction techniques at Caja de Agua are rough. ruses are actually not well made in terms of climate - But it must be remembered that it never rains in although the city is very foggy during the winter -Without rain the large soft bricks used between ncrete structure are valid, but the workmanship is

vast improvement in Caja de Agua over "barriada" is the availability of utilities and regular garbage on. Although occasionally the garbage collecmes less regularly than is desirable (see photograph te a lo que reemplaza. El planeamiento del proyecto en total es fácilmente visible. Areas abiertas y para parques existen con un desarrollo parcial de áreas verdes. Los jardínes que existen han sido ejecutados por los residentes.

Las técnicas de construcción usadas en Caja de Agua son muy toscas. Las casas no han sido bien diseñadas para el clima existente. Pero se debe recordar que nunca llueve en Lima, aunque la ciudad es muy húmeda y nebulosa durante los meses de invierno. Sin lluvia, los ladrillos grandes y suaves que se utilizan entre las estructuras de concreto son válidos pero la mano de obra es muy mala. 


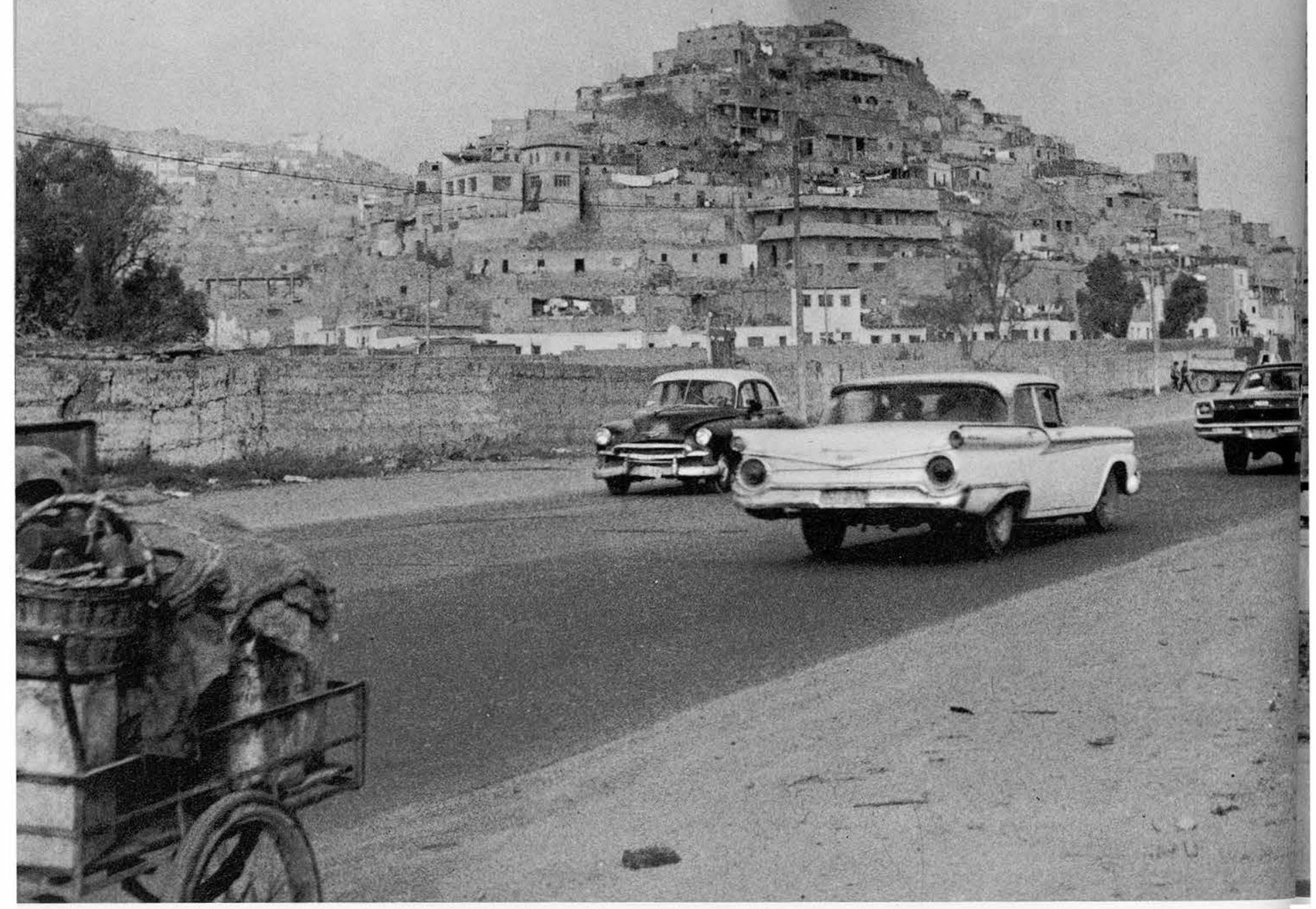

\section{Barriada San Cosme, Lima (21)}

28 ), it is not anywhere like the collection of debris found in "barriadas." The total visual impression of this project is unfavorable simply because it looks thrown together. The total project does not appear to be maintained by its inhabitants. Although evidence of additions to some of the houses is seen, very few have a clean, well cared for look, evidencing pride. Here again this attitude may be the result of hundreds of years spent under the will of a feudal lord. The downtrodden Indian may have lost certain values such as these from generation to generation, or, it may be an attitude
Un gran mejoramiento en Caja de Agua sobre vienda de barriada se encuentra en la existencia de $s$ públicos y especialmente el recogimiento regular de Aúnque la recogida de basura se ejecuta menos a men lo que se desearía (ver fotografía 28) no es la sil nada parecida a la recolecta de basuras en las barrial impresión total visual de este proyecto no es fa sencillamente porque parece ser armado despreocupada El proyecto no dá la impresión de ser mantenido | residentes, Aúnque se puede ver evidencia de adici algunas de las casas por sus residentes, pocas casas 


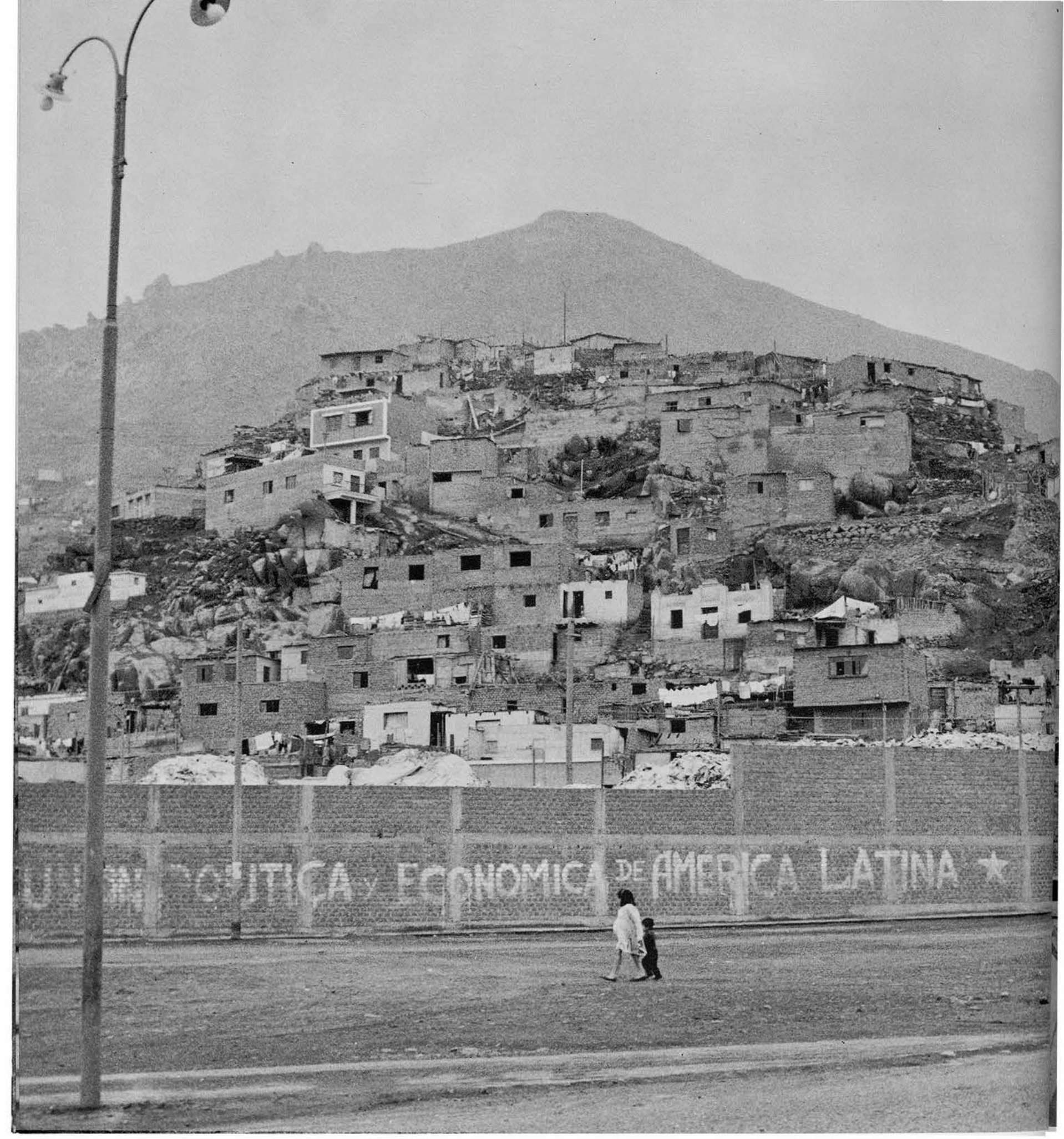

\section{Barriada San Cosme, Lima (23)}

during the Belaúnde administration, such as variety in size and location of housing units, enclosed spaces for not only children's recreation, but also for community meetings, and even solar consideration at window areas. Landscaping is provided by the individual owners.

Financing for prospective home ownership is based on ten-, fifteen- and twenty-year loans. This concept of public housing seems to work quite well for Perú-that is, government built housing units to be sold, rather than rented, as we have in the United States. It does reflect a pride of ownership by the individual, and the foreclosure rate cebido e iniciado bajo una administración anterior, el p total se dirige a la creciente clase media. La fase más de Mirones no tiene la misma buena calidad de plane que notamos en su última fase de construcción hechar la administración de Belaúnde la cual ofrece variedar tamaño y lugar de las unidades residenciales, espacio rrados no solo para juegos de niños sino también $p$ uniones de la comunidad y consideraciónes solares en de ventanas. $\mathrm{La}$ jardinería es ejecutada por los mismos! El financiamiento para la compra de estas unid basa en préstamos de 10,15 y 20 años. Este conct 


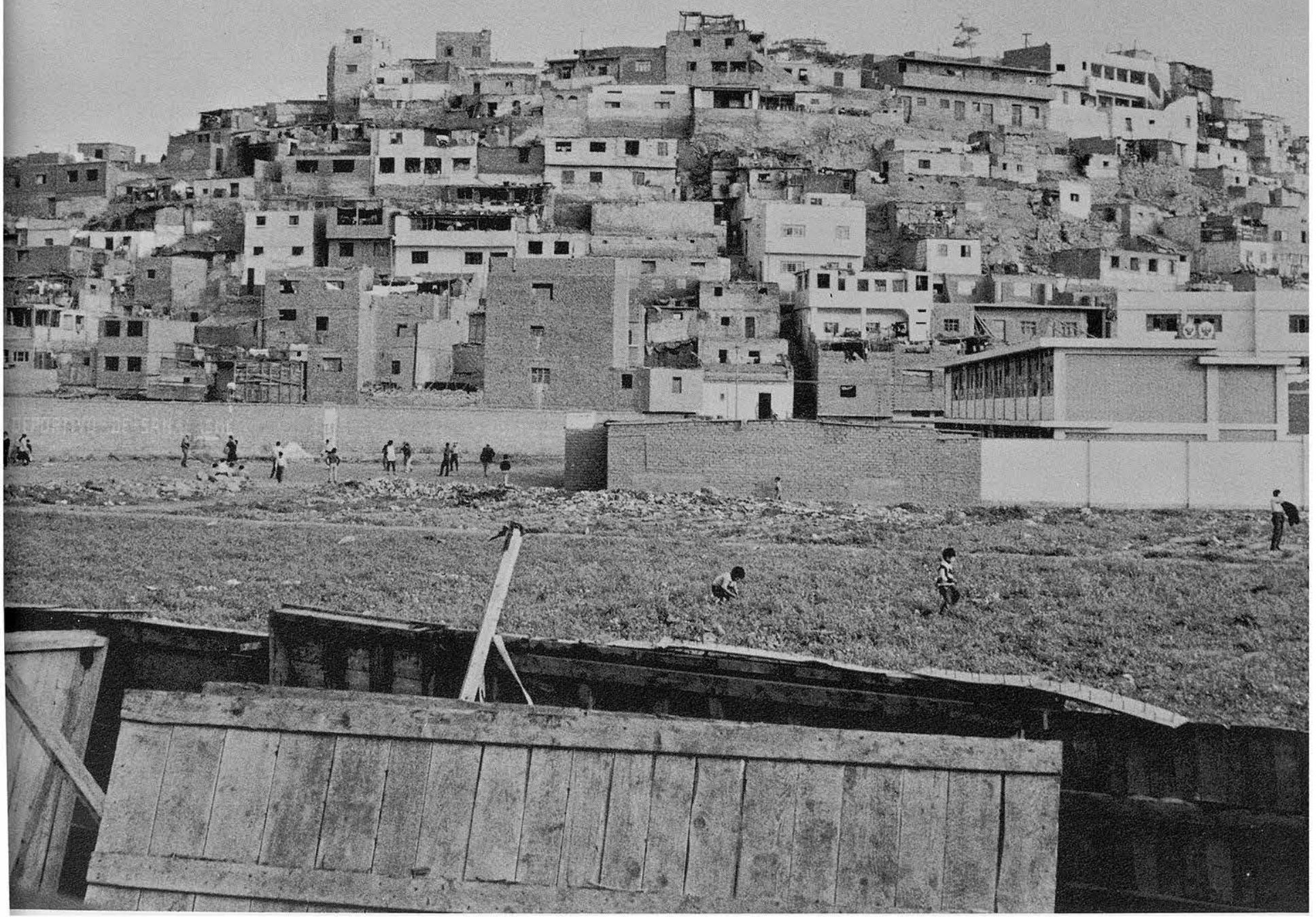

\section{Irriada San Cosme, Lima (24)}

aid to be very low. The United States' concept of housing uld, of course, prohibit the government from going into house for sale business.

Construction materials are basically all the same for total project. A painted, reinforced concrete frame is 1 for the structure. Various sized bricks are used as infill exterior walls, with plaster-covered single-thickness brick 1s dividing the interior spaces. Floors are of parkay wood concrete slab. The lower buildings are actually two floor is where active spaces such as living, dining and kitchen vivienda pública parece funcionar muy bien para el Perúes decir, unidades construídas para venta por el gobierno en vez de renta como se hace en los E.E.U.U. Refleja el orgullo de ser dueño del residente y el costo de la hipoteca es muy bajo. Nuestro concepto en los E.E.U.U. prohibiría al gobierno la construcción de casas para venta.

Los materiales de construcción son básicamente los mismos en este proyecto. Un marco de hormigón armado y pintado se utiliza para la estructura. Ladrillos no estructurales de varios tamaños se utilizan en las paredes exteriores para el tranque y paredes de un ladrillo de ancho (alicatado) 


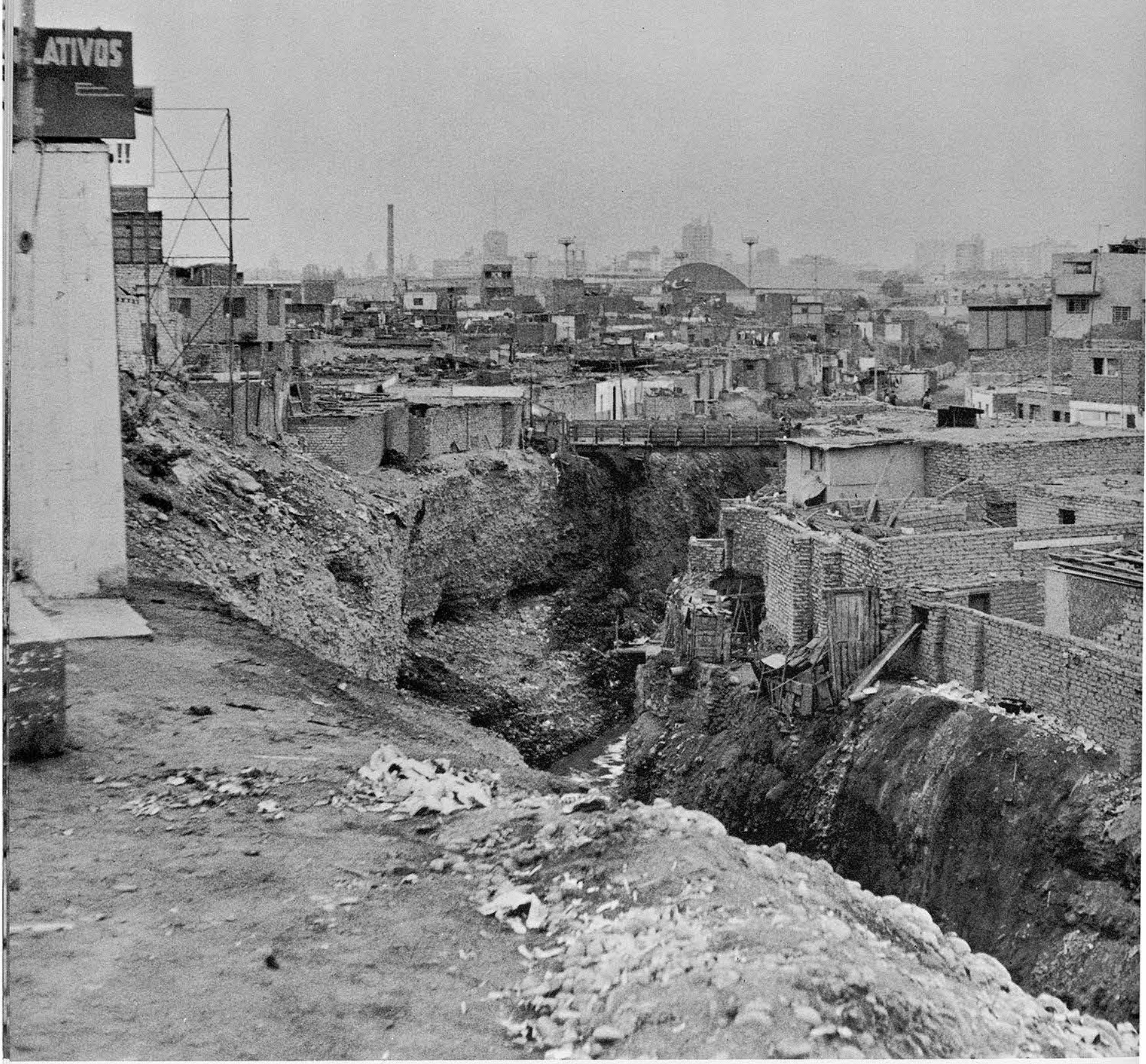

\section{Barriada, Lima (25)}

are on the first floor and bedrooms are placed above. Total space allotment seems minimum, but adequate.

Similarity can be noted in the concept of tower and townhouse living between Mirones and Santa Cruz. Santa Cruz (see photographs $37,38,39$ and 40 ) is a more refined statement of what was expressed first in the design of Mirones. Mirones is truly a community. It has a commercial center within the housing that contains "bodegas" (small grocery stores), a movie theatre, church, and even a trade school. The project has a core-a hub around which people living within the community relate to the design and their cubiertos con yeso para las paredes interiores. Los I primordialmente de madera parkay encima de conc1 edificios mas bajos son actualmente de dos pisc los espacios activos como sala, comedor y cocina se en en el primer piso y los dormitorios arriba. El espa distribuído parece ser mínimo, pero es adecuado.

Se puede notar una similaridad en el cons vivienda de torre y "townhouse" entre Mirones y Sat Santa Cruz (ver fotografías $37,38,39$ y 40 ) es un mas refinado de lo que primero se expresó en Mirones es realmente una comunidad. Tiene un ce 


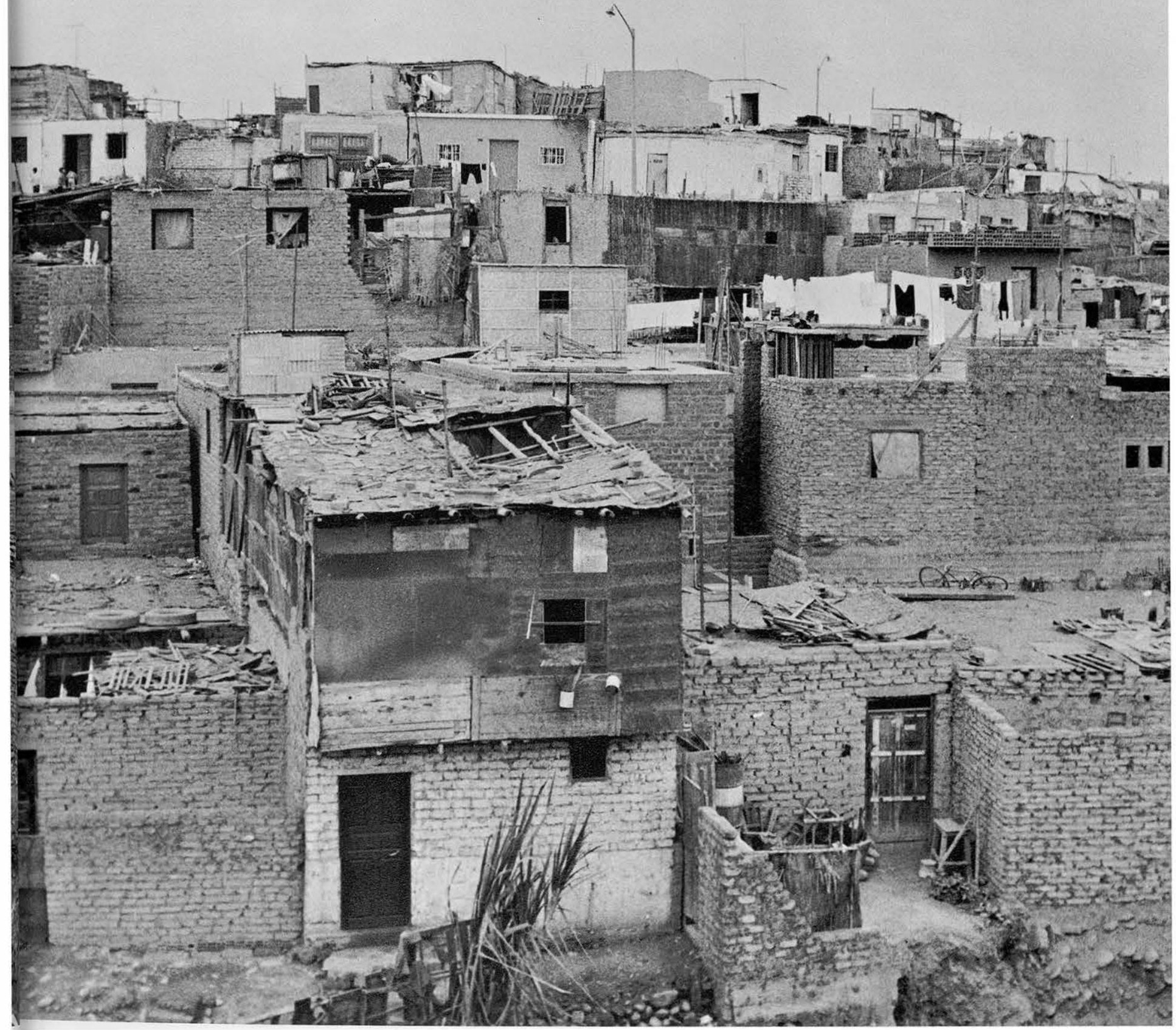

\section{arriada, Lima (26)}

solvironment. The demand for this type of housing is signito ed by the fact that it is totally occupied. An acute fusing shortage does exist in Lima, but that fact alone Iet not the reason Mirones is filled.

Close to Mirones in location is yet another government rusing project named Palomino. If the economic middle $\mathrm{p}^{\text {pss }}$ could be divided in half, the upper middle class could ${ }_{2}$ y. claim to Palomino. It is new, just an initial stage of a oiry large total development. The second stage is not comwited. Here again painted reinforced concrete is the prime tot terial used. But this project differs in concept from mercial entre las viviendas que contiene bodegas, un cine, iglesia y aún una escuela (de artes y oficios o industrial). El proyecto tiene un centro de actividad en el cual los residentes se relacionan con el diseño y el ambiente total del lugar. Prueba de la demanda para este tipo de vivienda se puede apreciar en la no existencia de vacantes. En Lima existe una falta de vivienda notable pero ésta no es la única razón por la cual Mirones está lleno.

Cerca de Mirones se encuentra otro proyecto del gobierno llamado Palomino. Si se pudíera dividir a la clase económica media en dos grupos, el grupo más alto podría 



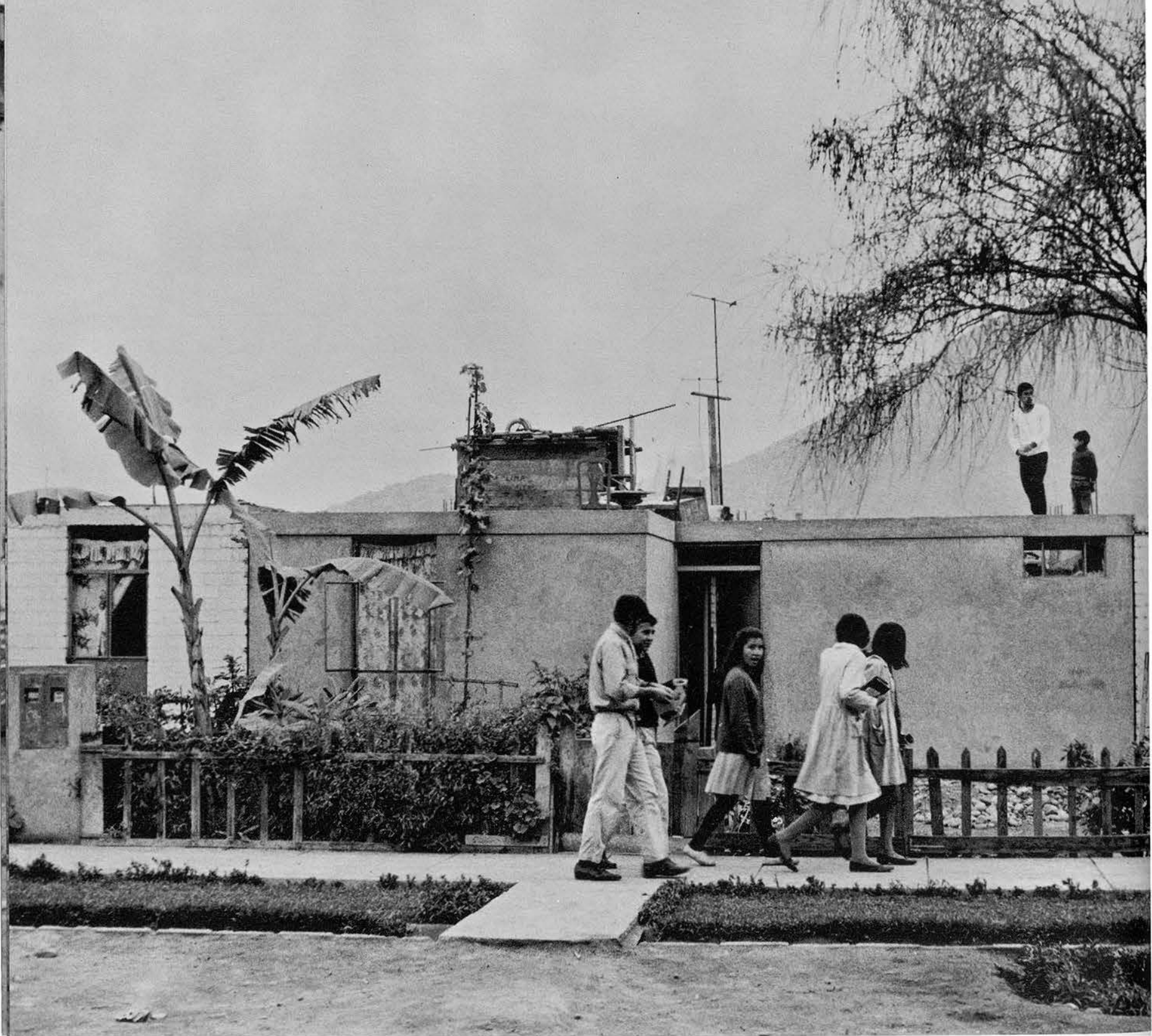

Caja de Agua, Lima (29)

and construction is evident when contrasted with Caja de Agua. This is a painted reinforced concrete design with variations of size and type of housing. Most of the housing is concentrated in five floor towers; these five floors actually consist of three housing units vertically. The top four floors are two housing units, each with two floors.

Enclosed open spaces between the towers provide good areas for children to play and add tremendously to the environment of the project. Even outdoor furniture such as benches and planters reflects a consciousness for design and atmosphere. Parking areas are provided independently from por corporaciones mutuales con un soporte eviden Banco de la Vivienda del Perú. Se nota una m diferencia con Caja de Agua en la calidad de planean diseño y construcción. Los edificios son de hormigón at pintado y con variaciones de tamaño y tipo de vivien mayoría de las unidades de vivienda se concentran en de cinco pisos; estos cinco pisos consisten de tres unidy viviendas verticales. Los pisos mas altos consisten unidades de vivienda, cada una de dos pisos.

Espacios abiertos limitados por las torres provéen lugares para que los niños jueguen y contribuyen e 


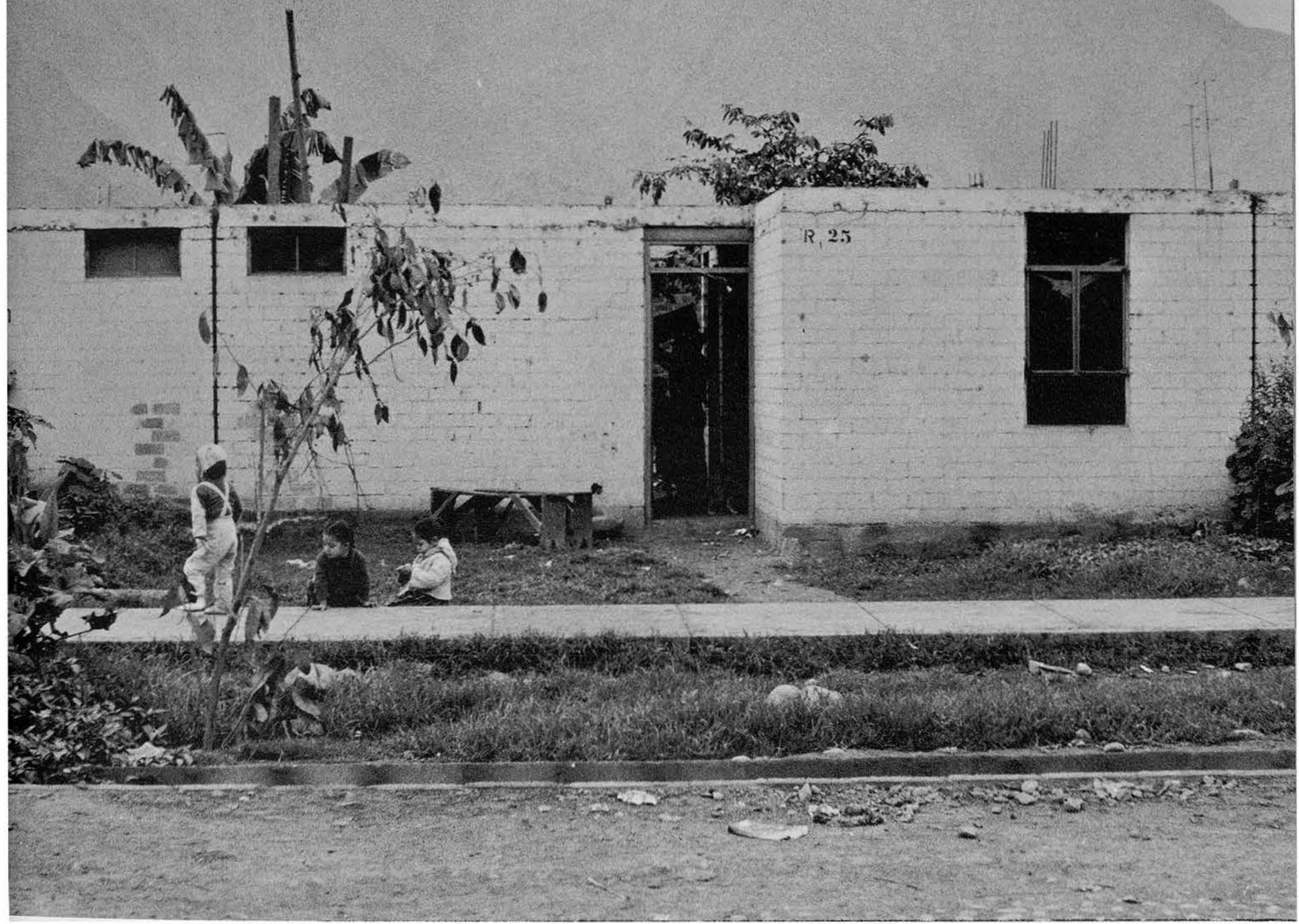

\section{ja de Agua, Lima (30)}

residential units. Only a service road penetrates the tior of the project to a shopping center for the intants.

A limited number of independently detached units, ar to a townhouse type of arrangement, lend variety to scope of the project. These, of course, are higher in but afford more privacy. The difference in atmosphere his project from that of Caja de Agua expresses very $\mathrm{h}$ to the viewer. This project does have that cared for rance lacking in Caja de Agua. It reflects education, I custom and attitude differences between classes. parte al ambiente del proyecto. Hasta los muebles de exterior como bancos y canteros reflejan la preocupación por el diseño y carácter del lugar. Hay áreas de parqueo independientes de las unidades residenciales. Solo una calle de servicio penetra hacia el interior del proyecto hasta un centro comercial para los residentes.

Hay un pequeño número de unidades independientes, similares al tipo "townhouse," que proporcionan variedad y extensión al proyecto. Estas por supuesto son más caras pero ofrecen mas privacidad. $\mathrm{L} a$ diferencia en ambiente entre este proyecto y Caja de Agua le dicen mucho al espectador. Este 


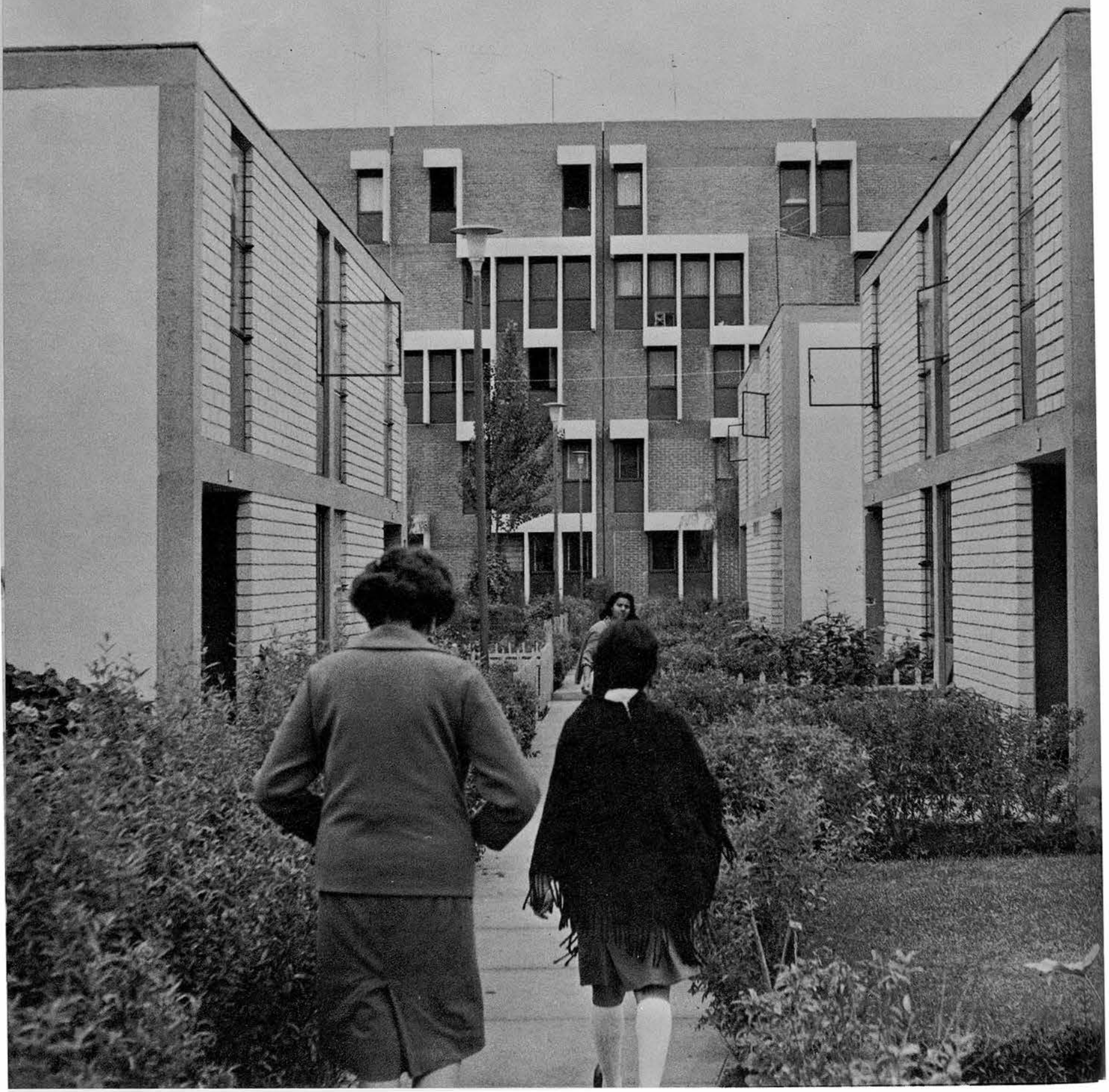

\section{Mirones, Lima (31)}

One of the most controversial developments that has come from President Belaúnde's administration, came over the government housing project known as San Felipe. It was conceived and intended for the middle economic class, but because of costs involved, it has been said that most people in that class are unable to afford to buy there. It has also been criticized sharply by opponents of the current administration as a "pork barrel project" and one that ran out of funds for continued construction before completion.

San Felipe is the only high rise government housing project in Lima. It is a truly massive development that proyecto sí tiene ese aspecto de cuidado que falta $e$ de Agua. Refleja la educación, costumbres sociales yd cia de actitud entre las clases.

Uno de los proyectos más discutidos que ha surg la administración de Belaúnde es el proyecto llamad Felipe. Se concibió para la clase económica media pa razónes de costos, se ha dicho que estas personas no ll poder comprar allí. También se le ha criticado col proyecto arreglado, para el cual se agotaron los fondo de su terminación.

San Felipe es el único proyecto de vivienda of 


\section{rones, Lima (32)}

ald have been recognized in the United States before $r$ (see photographs 41 through 48). Whether or the need of an answer for middle class housing is illed is a matter for strong debate. Twelve thousand ars is the minimum price for a housing unit. Architecllly speaking, it is a very bold statement of how Peruvian itects working for the Junta Nacional de la Vivienda that massive housing developments should be designed $\mathrm{n}$ urban space.

The site is that of the old hippodrome (262,236 sq. ers), which is surrounded by middle class housing on bierno de múltiples pisos. Es realmente un proyecto inmenso que debía haber sido reconocido en los E.E.U.U. anteriormente (ver fotografías $41,42,43,44,45,46,47$ y 48). Si la necesidad de viviendas para la clase media ha sido satisfecha o no es un punto que se presta a discusión. El precio mínimo por unidad es de $\$ 12,000$. dólares. Hablando arquitectónicamente, es una interpretación intrépida de diseño para unidades de vivienda urbanas por parte de los arrquitectos de la JNV.

El sitio es el del antiguo hipódromo (260,736 metros cuadrados) el cual está limitado por viviendas de clase media 


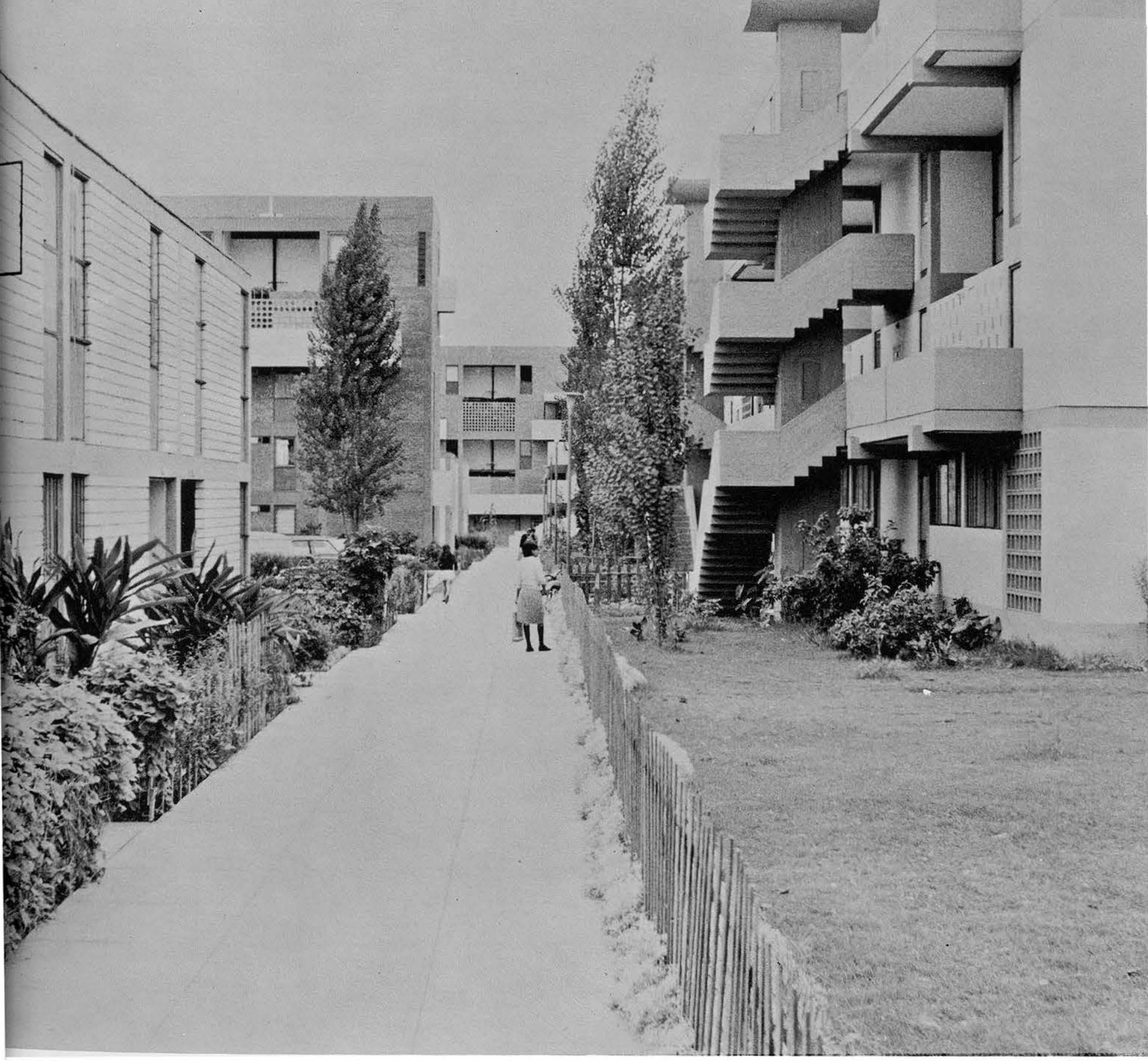

Virones, Lima (34)

The entire project is to contain 1,599 housing units f various sizes. It is programmed for a population of 9,554 eople, which breaks down to 365 inhabitants per hectare. this is considered medium density housing for Lima. Of he total site area only 23.6 percent is covered by buildings. he remainder will be devoted mostly to landscaped open jaces.

An interesting restriction placed upon home ownership 1 San Felipe is that no one can buy there if he already owns sidential property in Lima. This attests to the acute housig shortage. A study conducted by the Oficina Nacional
El proyecto entero deberá contener 1,599 unidades de varios tamaños. Se planea para una población de 9,554 personas, lo que indica 365 habitantes por hectárea. Esto se considera vivienda de densidad media para Lima. Del sitio total solo 23.6 porciento está cubierto de edificios. El resto se dedicará a paisaje y jardínes.

Una restricción interesante que se ha puesto para la compra de alguna unidad en San Felipe consiste en que nadie puede comprar allí si ya es dueño de alguna propiedad residencial en Lima. Esto confirma la falta de viviendas en Lima. Un estudio hecho por la Oficina Nacional de Planeamiento y 


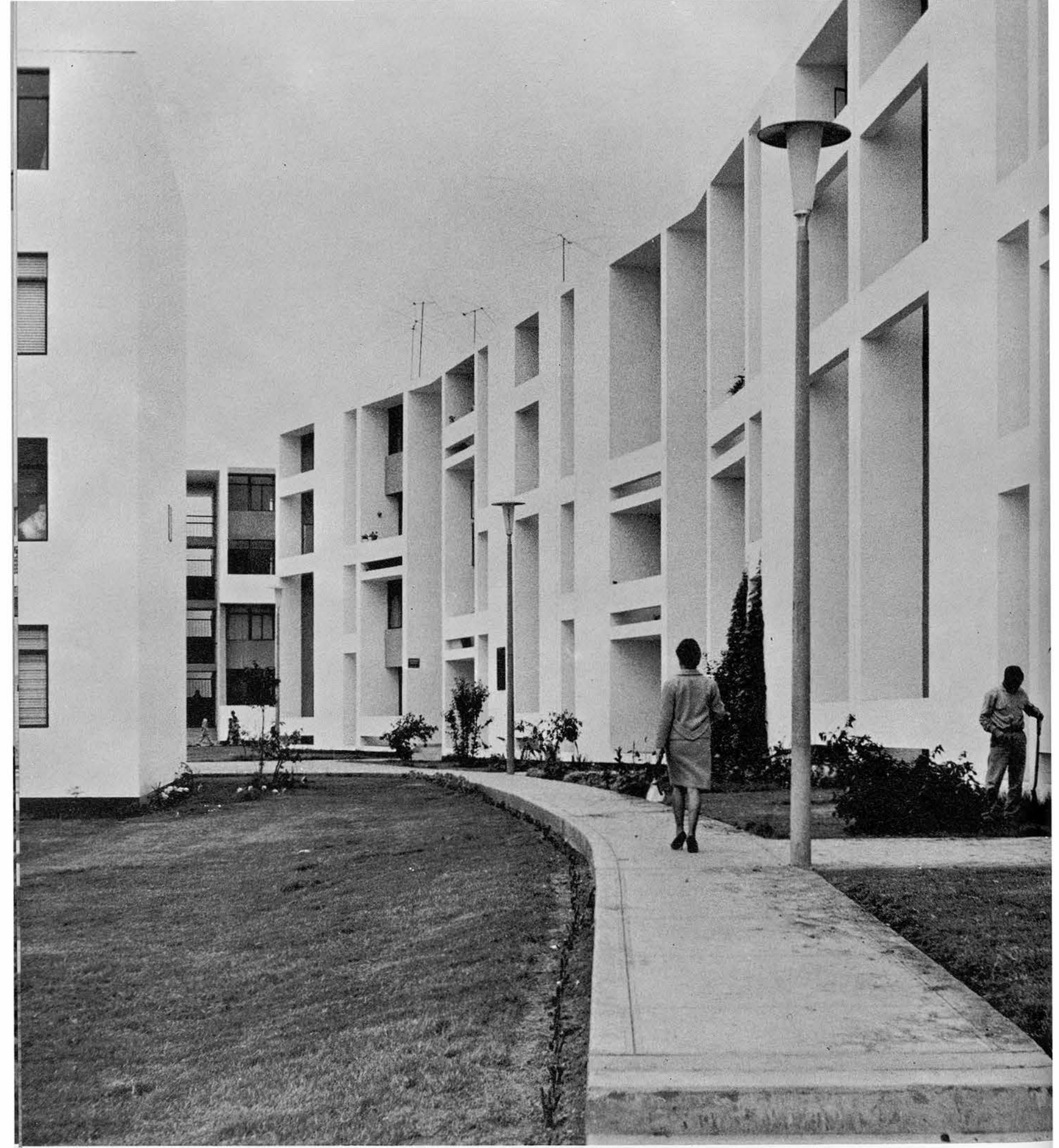

Palomino, Lima (35)

de Planeamiento y Urbanismo (National Office of Planning and Urbanization) projected the population of Lima in 1980 to be $4,699,200$, and by the year 2000 to be $11,820,300$. If low rise residential construction were to continue based upon a population density no greater than 200 people per hectare, Lima would have to expand by 19,260 hectaresphysically triplicate in size. This is considered impossible because expansion of utilities to the added areas would present insurmountable obstacles. San Felipe, then, is considered medium density housing based upon future conditions. Other than housing, San Felipe will eventually contain three kin-
Urbanismo proyecta la población de Lima en 19 $4,699,200$ y para el año 2000 debe ser $11,820,300$. siguiera la construcción de pocas plantas para una pob de una densidad de no más de 200 personas por hec Lima tendría que agrandarse 19,260 hectáreas, o sea tri su tamaño. Esto sería imposible porque la expansión empresas de servicios públicos presentarían un obst invencible. Por consiguiente, a San Felipe se le con vivienda de densidad media basada en condiciónes futur: adición a unidades de vivienda, San Felipe tendrá en elf tres kindergarten, un colegio, 71 tiendas, un supermerc 


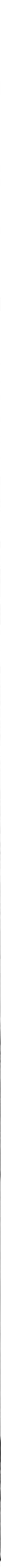

alomino, Lima (36)

rgartens, a school, seventy-one stores, one super market, id a church. Also on the site is located a Japanese cultural nter. Underground service to most of these facilities is inned. The first stage now completed has underground rking for its 268 apartments. But the underground park$?$ is not being continued throughout the total project due imarily to the furor about cost.

There are two types of housing designed for the first ge. They are the duplex, or lower storied apartments (onenily house) and the flats in the towers (multi-family vers.) The duplex contains a living-dining area, three una iglesia. También tiene un centro cultural Japonés. Se planea servicio bajo tierra para la mayoría de estos edificios. La primera fase ya completada tiene parqueo bajo tierra para los 268 apartamentos. Pero no se continuará el parqueo bajo tierra para el proyecto total por razones de costo principalmente.

Hay dos tipos de vivienda diseñados para la primera fase. Son el dúplex, o departamento de primer piso (para una familia) y los "flats" en las torres (torres multifamiliares). El dúplex contiene un área de sala-comedor, tres dormitorios, un baño, cocina y patio, y cuarto y baño para servicio. 


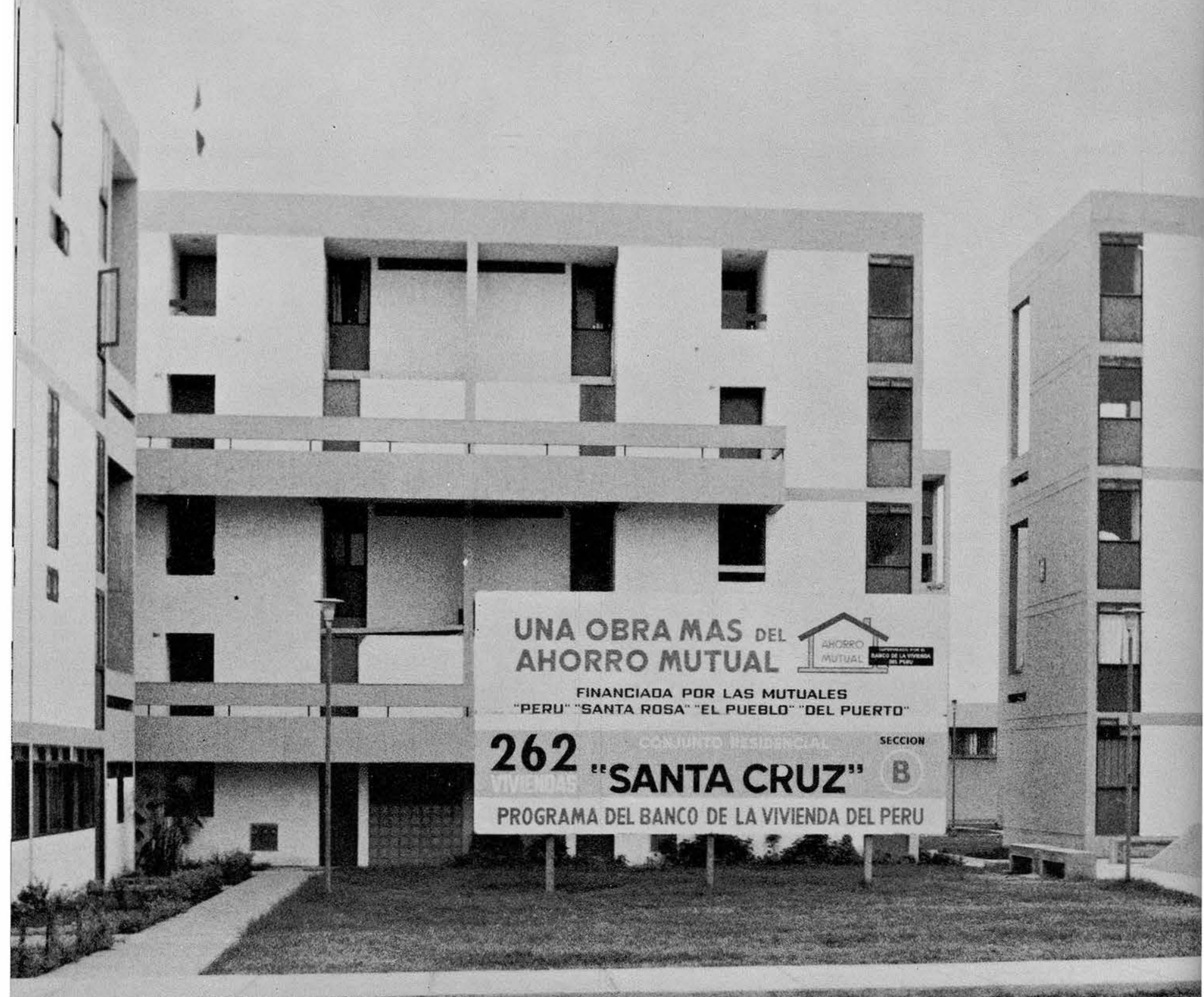




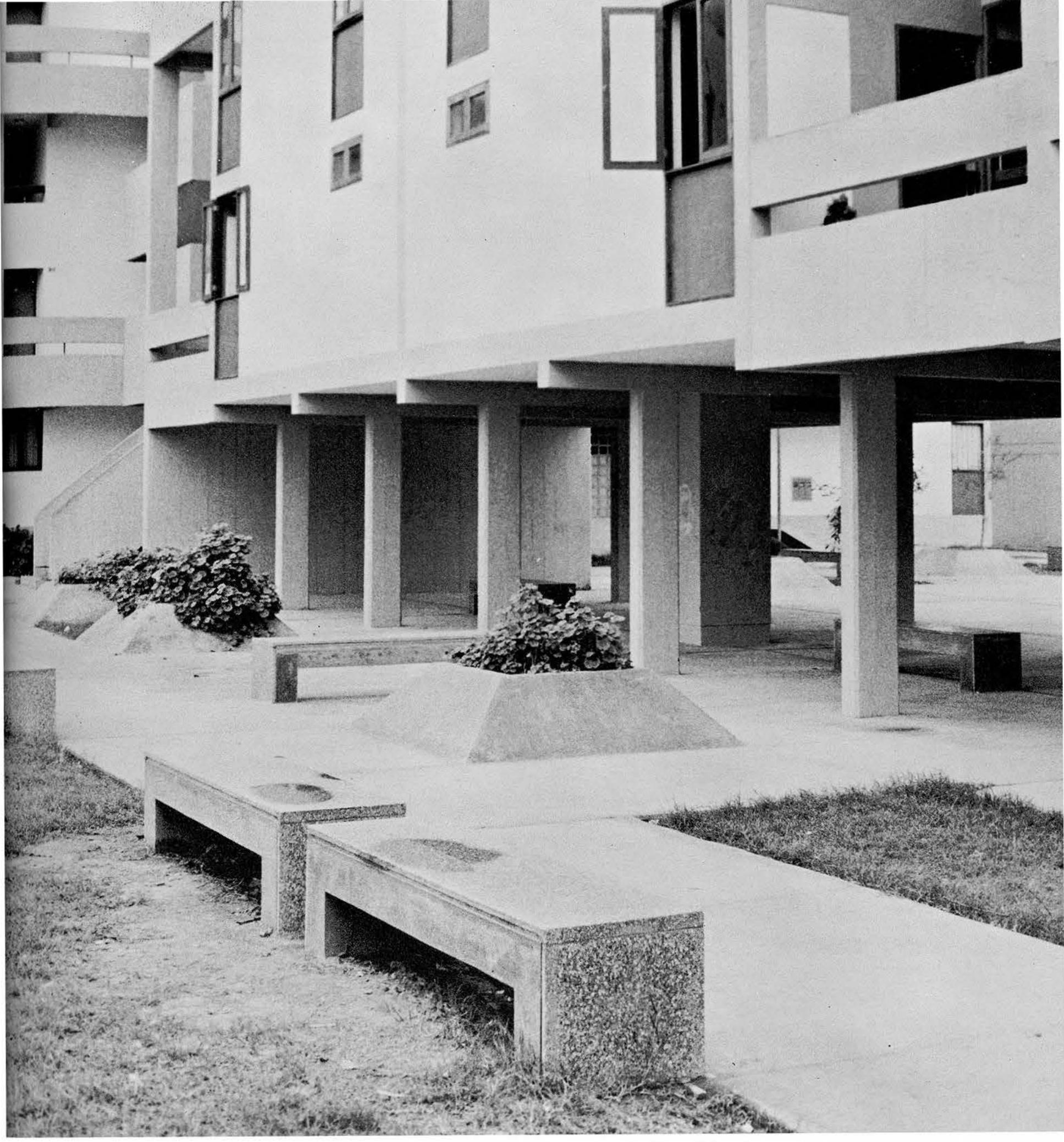

\section{Santa Cruz, Lima (38)}

cluded in tower living is an incinerator, doorman, telephone and intercom, and two elevators serve the twelve living floors. The price is $\$ 13,800$ (dollars) with the same down payment and financing terms as for the duplex. Banco Central Hipotecario de Lima handles the financing. Monthly mortgage payments in the first stage of San Felipe are approximately $\$ 100$ to $\$ 115$ (dollars).

Construction techniques and material used at San Felipe are among the best seen for government housing in Lima. Reinforced concrete is the prime material used in the first stage. A very noticeable material used throughout the de $\$ 13,800$ (dólares) con la misma cuota inicial y términos de financiamiento que para el dúplex. El financiamiento se hace por medio del Banco Central Hipotecario de Lima. Los pagos mensuales en la primera fase de San Felipe son aproximadamente de $\$ 100$ a $\$ 11$ (dólares).

$\mathrm{La}$ técnica de construcción y los materiales utilizados en San Felipe están entre los mejores que he visto para vivienda del gobierno. El hormigón armado es el material básico principal utilizado en la primera fase. Para las ventanas se ha utilizado madera, lo cual proporciona un contraste agradable junto a la abundancia de concreto. La nueva fase 

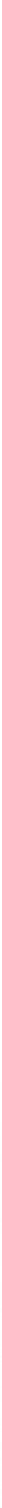

\section{Santa Cruz, Lima (40)}

fast rising Lima middle class have been good. Where the program apparently falls short is in housing for the lower economic class of people. The government's efforts there are falling far short.

Another personal criticism this viewer has of the design in the government housing concerns the social custom still retained of providing servants' quarters in the housing unit. Customs of the past such as this have no place in middle ncome government housing. It is a point to debate with a Peruvian family, most of whom have a very strong sense of class distinction. They feel that servants are mandatory baja. Los esfuerzos del gobierno en éste aspecto no han sido suficientes y dejan mucho que desear.

Otra crítica personal de este observador en cuánto al diseño de las viviendas del gobierno consiste en la costumbre social que se mantiene en el Perú de tener cuarto y baño de servicio. Las costumbres del pasado como ésta no tienen lugar en viviendas del gobierno para clase media. Este es un punto de discusión con respecto a la familia Peruana, la mayoría de las cuales tienen concíencia de una diferencia de clases muy fuerte. Piensan que es absolutamente necesario tener sirvientes para poder administrar bien una casa. Pero, 


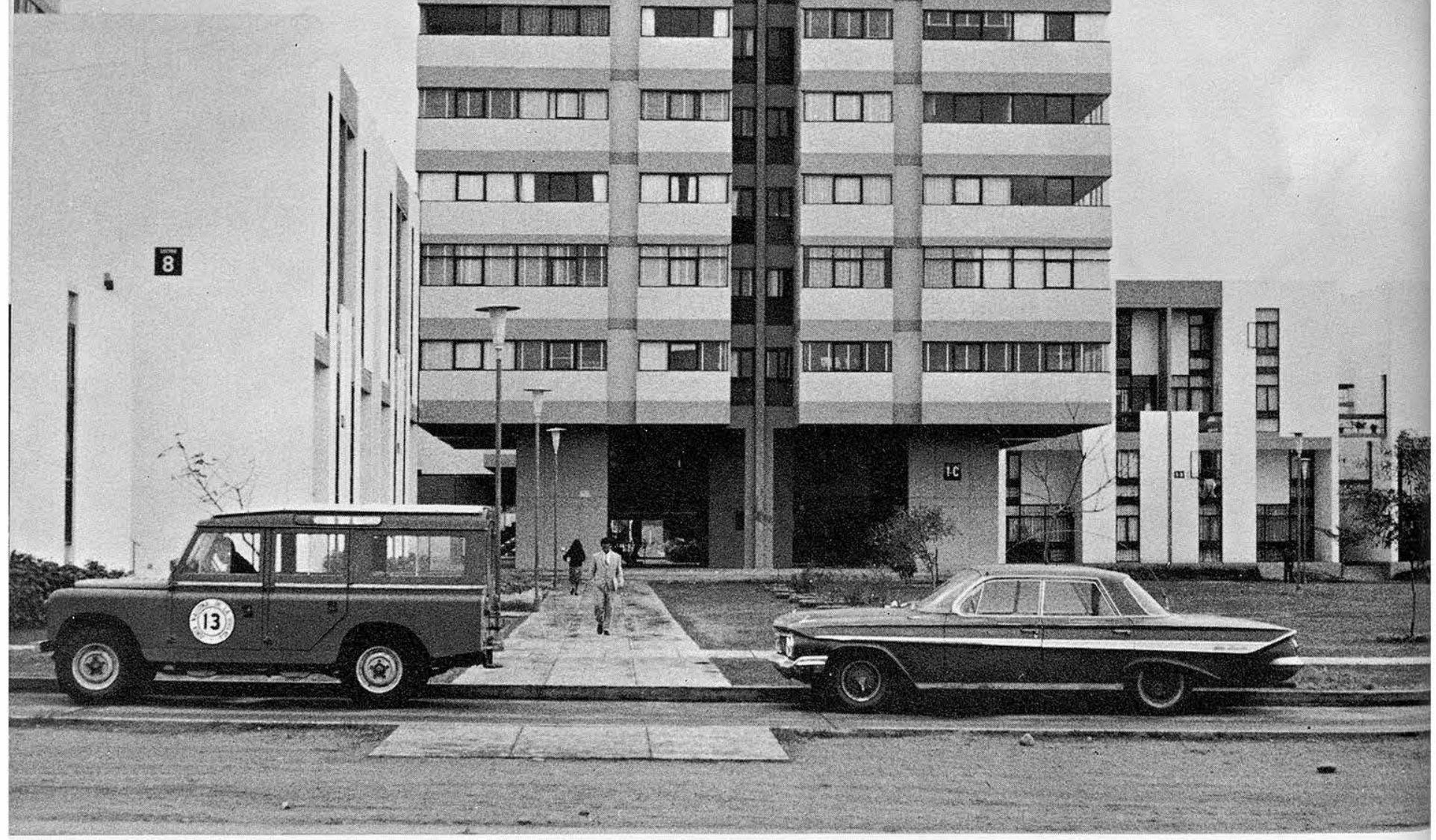

San Felipe, Lima (41)

to run a household. But, is the expense justified for a nation that is striving to overcome many past barriers that have kept it from progressing economically?

In 1961 the Peruvian government, sensing the approach of a critical housing situation, invited IBEC (International Basic Economy Corporation) to Perú for the expressed purpose of building housing for the lower economic classes. IBEC was founded with Rockefeller backing and its activities are concerned with raising the standards of living in various parts of the world. Its total activities break down ¿es justificable este gasto para una nación que está tratal de sobreponerse a muchas barreras anticuadas que la b atado en su progreso económico?

En 1961 el gobierno Peruano, dándose cuenta del ara del problema de la vivienda, invitó al IBEC (Internatio Basic Economy Corporation) al Perú con el propósitol construir viviendas para las clases económicas bajas. El $\mathbb{B}$ se fundó con fondos de Rockefeller y sus actividades of ciernen a levantar el estandard de vida en muchos lugares mundo. Sus actividades en total se dividen en los siguien 


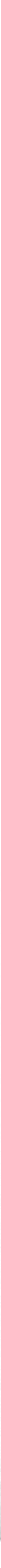

San Felipe, Lima (42)

into five groups. They are: housing; food; poultry; industrial and funds; investment and insurance.

The first housing project IBEC did was in Lima and is known as Salamanca de Monterrico (see photographs 49 and 50). It was a 1,509 unit lower class housing project located on an area of more than 40 hectares of land off the Panamerican highway in southern Lima. The total cost for the investment was \$7.5 million dollars. Perú's National Housing Bank (Banco de la Vivienda) granted a $\$ 4$. million (dollar) mortgage-financed loan, and the Agency for International Development (AID) provided a $\$ 2.5$ million grupos: vivienda; alimentación; avicultura; industria y financiamiento; inversión y seguros.

El primer proyecto de vivienda que realizó el IBEC en Lima se conoce por el nombre de Salamanca de Monterrico (ver fotografías 49 y 50). Es una unidad de 1,509 casas para la clase media baja localizada en un área de más de 40 hectáreas de tierra cerca de la carretera Panamericana, al sur. El costo total fué de $\$ 7.5$ millones de dólares. El Banco de la Vivienda proporcionó $\$ 4$ millioñes de dólares de préstamo hipotecario y la Agencia para Desarrollo Internacional 


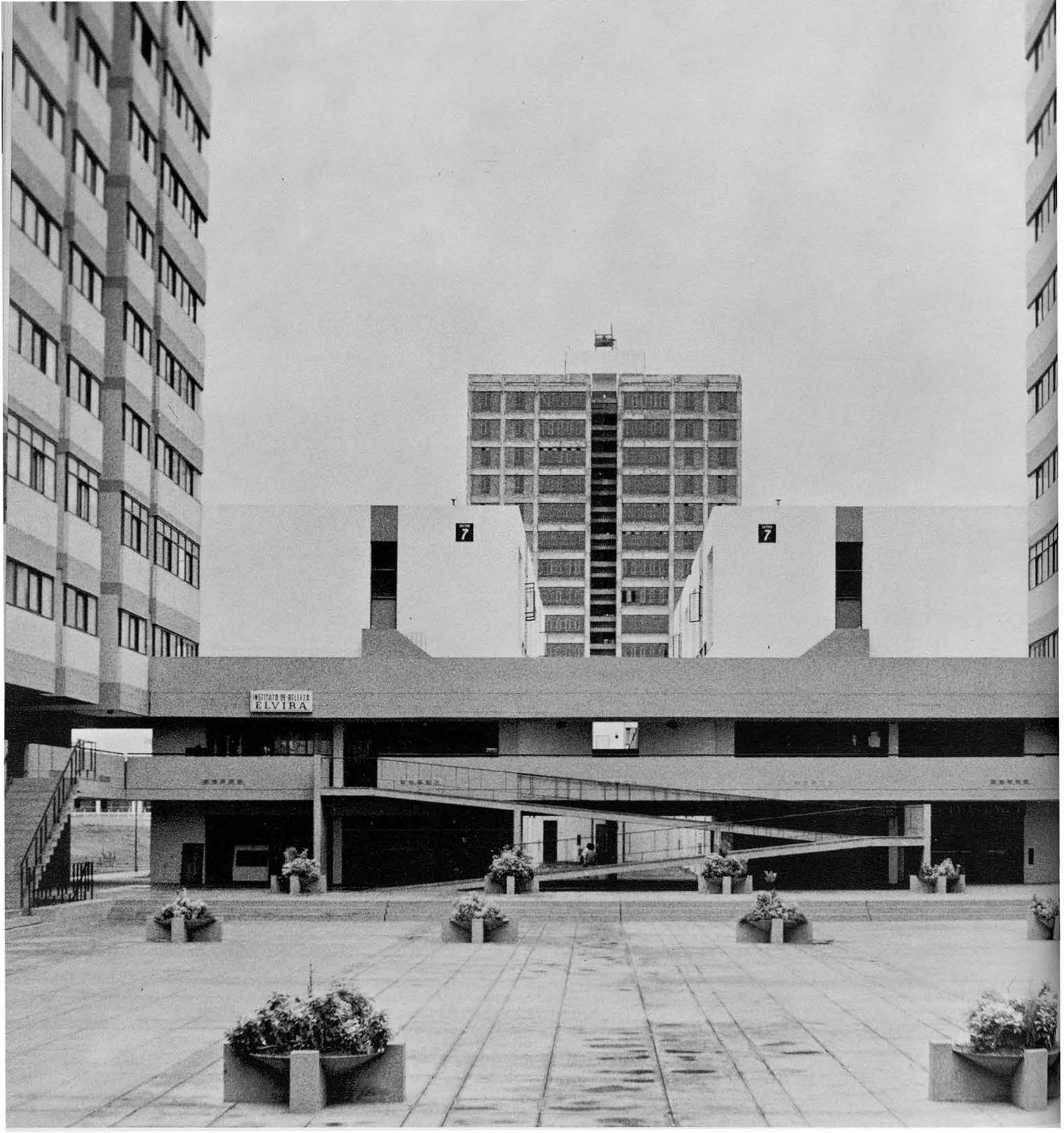

San Felipe, Lima (43)

(dollar) mortgage-financed loan. Prospective home owners obtained mortgages from savings and loan associations. Two percent of the land is decreed by law to be used for public services, such as fire and police stations, schools and churches, etc.

A forward looking Lima architectural firm designed the project. All the homes are of similar design using the standard construction materials locally available of brick and tile and reinforced concrete. Designed were two, three, and four bedroom units (only thirty two-bedroom units were built. There was little demand for them.)
(AID) proporcionó $\$ 2.5$ milliones de dólares de préstart hipotecario.

Los compradores obtuvieron préstamos de las asocir ciones de préstamos y ahorro. El dos porciento de la tierra decreta por ley para el uso de los servicios públicos, tals como estación de bomberos, policía, colegios e iglesias, eth

Una firma de arquitectos Peruanos muy progresistr diseñó el proyecto. Todas las casas son de diseño simis usándose los materiales de construcción fácilmente obtenibla como ladrillo, lozas y el hormigón armado. Se diseñartu unidades de dos, tres y cuatro dormitorios aúnque solos 


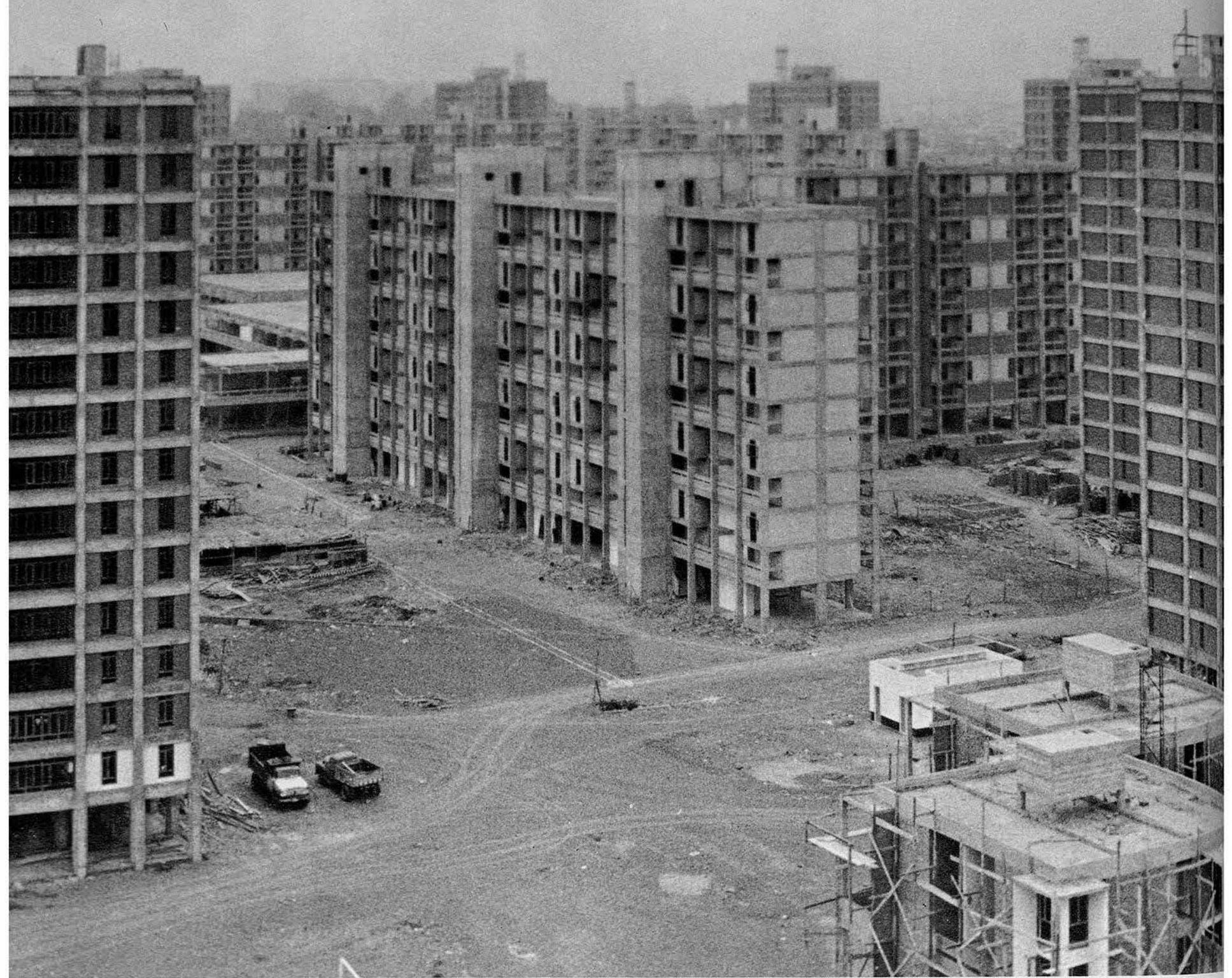

\section{San Felipe, Lima (45)}

thropic organization, but to the contrary, it enters into an investment to make money. It expects 30 percent per year minimum profit. In the case of Salamanca, IBEC owned the land, hired the architects, subcontracted the construction, but maintained supervision of the project. It built 1,000 houses over a period of 5 years relying upon local financial resources.

IBEC's position of importance in the Peruvian housing picture is secure. It is doing a job which the government has partially neglected, that is, trying to provide better housing for the lower class of people. In fact, the Salamanca
Salamanca ha sido un éxito para el IBEC y para é gobierno Peruano. El IBEC parecerá una organizaciór filantrópica, pero, al contrario, ellos invierten para ganal dinero. Esperan ganar el 30 porciento al año como gananci mínima. En el caso de Salamanca, el IBEC era el dueño de terreno, contrataron a los arquitectos, subcontrataron construcción, pero mantuvieron la supervisión del proyecto Se construyeron 1,000 casas durante un periodo de 5 año dependiendo de financiamiento local.

El puesto de importancia del IBEC en la vivienda de Perú es seguro. Está hacíendo una labor que, en parte, ha sid 


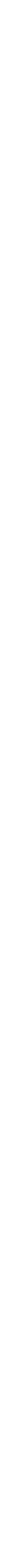

\section{n Felipe, Lima (46)}

ject was so successful, geared as it was to lower income ple, with good planning, design and low costs, that it acted people from higher income groups to buy. Army icers and young professionals and even a couple of conismen have moved into the project, which now has a ulation of more than 10,000 people.

At the present time IBEC is engaged in another sing project for northern Lima, called Del Norte. It lot for a higher income population but it is for an even er income population than Salamanca. How can it be e? It is done by the imagination and ingenuity of the abandonada por el gobierno, o sea, el tratar de proveer mejor vivienda para la clase económica baja. En efecto, el proyecto de Salamanca tuvo tanto éxito, dirigido como estaba hacía las personas de menos facilidades económicas, bien planeado con buen diseño y costos bajos, que atrajo a muchas personas de situación económica más alta. Hay viviendo en Salamanca oficiales del ejército, profesionales jóvenes y hasta varios senadores y diputados. Hoy en dia su población es de más de 10,000 personas.

Por el momento, el IBEC ha iniciado otro proyecto para la parte norte de Lima, llamado Del Norte. Este no es para 


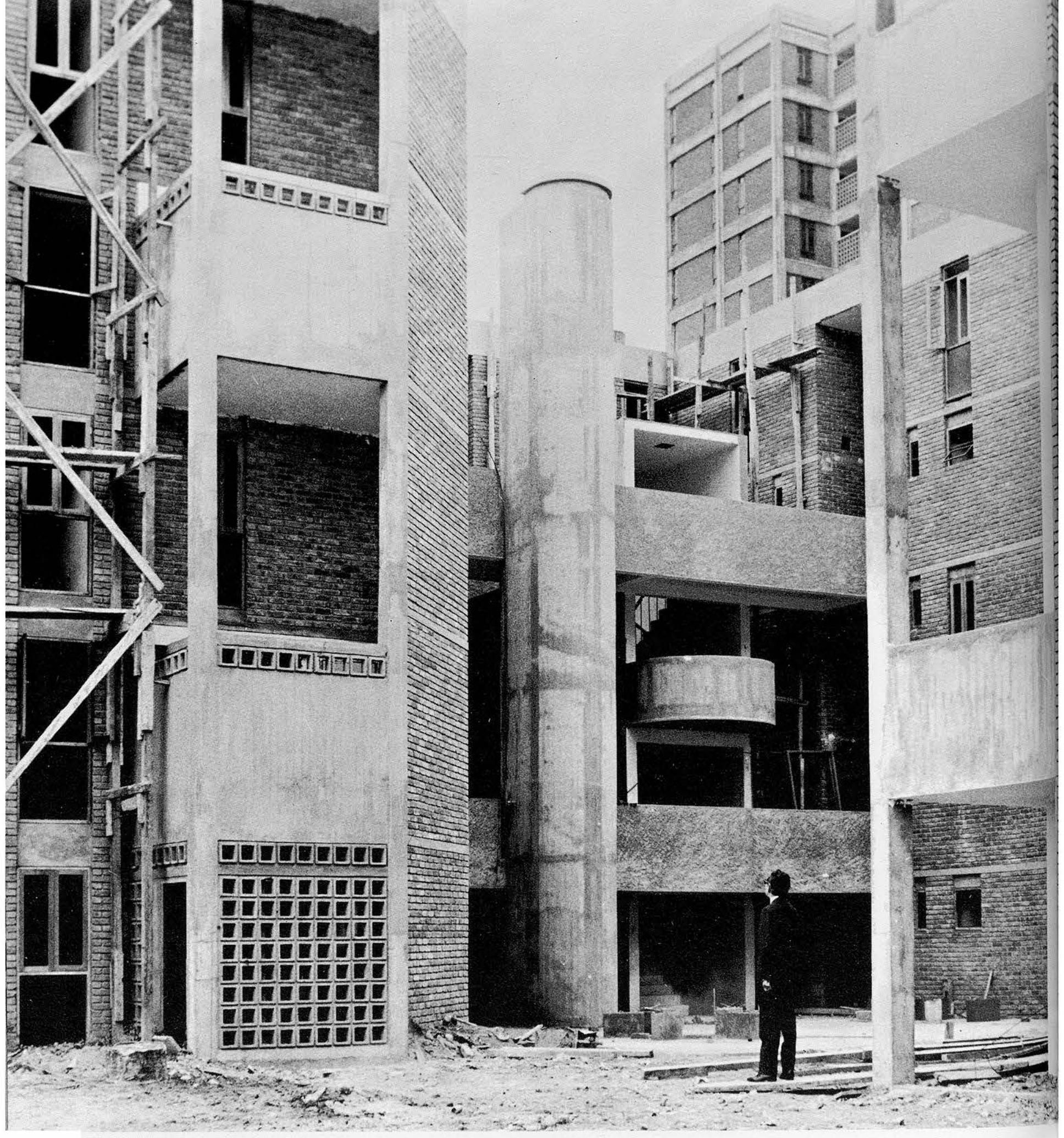

\section{San Felipe, Lima (47)}

same firm of architects. The new project will contain 1,200 units of identical quality to Salamanca.

The way the savings in cost will come about is through a historical type of roofing system. Instead of the now customary concrete or brick roof, the architects have decided to place about a four inch layer of dirt over an "estera" mat supported by bamboo beams imported from Ecuador. It doesn't rain in Lima so, therefore, no deterioration or erosion will take place. The savings will amount to approximately $\$ 745$ (dollars) per unit.

A broad coverage of housing in Lima would not be un grupo de situación económica mas alta, sino para los de situación económica aún mas baja todavía que Salamanca ¿Como se puede hacer? Se hace con la imaginación y la inventiva de la misma firma de arquitectos progresistas. El nuevo proyecto comprenderá 1,200 unidades de la misma calidad que Salamanca.

El ahorro en costo se realizará por el uso de un tipo de techo histórico. En vez de usarse los materiales acostumbrado como concreto y techo de ladrillo, los arquitectos han decidido echar una capa de 4 pulgadas de tierra encima de estera sosteniendola con vigas de bambú importadas del 


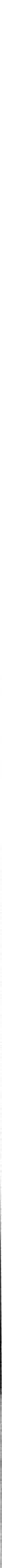

I Felipe, Lima (48)

iplete without mentioning the new finer residential area Monterrico (see photographs 51, 52, 53 and 54). In south Lima area rough barren mountains have been isformed into an exclusive, and in most cases lush, area living. The homes photographed are representative of custom designs found there. Pitched roofs are of no ie, and are rarely found. More care is now taken in the 3n to careful detailing and material choices in these finer es. Materials such as imported woods for paneling and tifully crafted stone walls now have greater value in yn. Large expanses of glass allow the residents a vista
Ecuador. Como no llueve en Lima, no se deterioran los materiales. Se ahorrará apróximadamente unos $\$ 745$ (dólares) por unidad.

Al tratar de hacer un estudio de la vivienda en Lima no se puede dejar a un lado el área de residencias selectas de Monterrico. En este lugar sureño de Lima se han transformado áreas de montañas ásperas y áridas a un barrio para vivir exclusivo, y en muchos casos, lujoso. Las casas fotografiadas son típicas de las diseñadas para este lugar. (Ver fotografías 51, 52, 53 and 54.) Los techos de dos aguas no se necesitan, por lo tanto no se encuentran a menudo. Se 


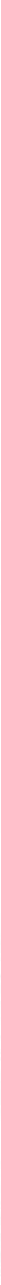

\section{Salamanca, Lima (49)}

down the mountain and of the skyline of Lima beyond. That vista is best during the months of October through May when the fog from the ocean is not present. All of the photographs presented were taken during Lima's winter when distances are hard to view because of the weather.

The housing problem in Lima is similar to that which we know in the United States. In both cases economics, social customs and distinctions as well as education enter into the picture. But, the housing problem in Lima is of more serious proportions despite the most recent efforts of the government to try and alleviate the situation. The toma mucho cuidado en el diseño de los detalles y la selección de materiales para estas casas selectas. Los materiales como madera importada para paneles y piedra trabajada para paredes tienen mucho valor en los diseños. Grandes paños de vidrio permiten a los residentes una vista hacía abajo de las montañas y de la ciudad de Lima a lo lejos. Esta vista es mucho mejor durante los meses de Octubre hasta Mayo cuando la garúa no existe. Todas las fotografías tomadas para este escrito se tomaron durante el invierno Limeño y las distancias no se ven claramente por el clima. 


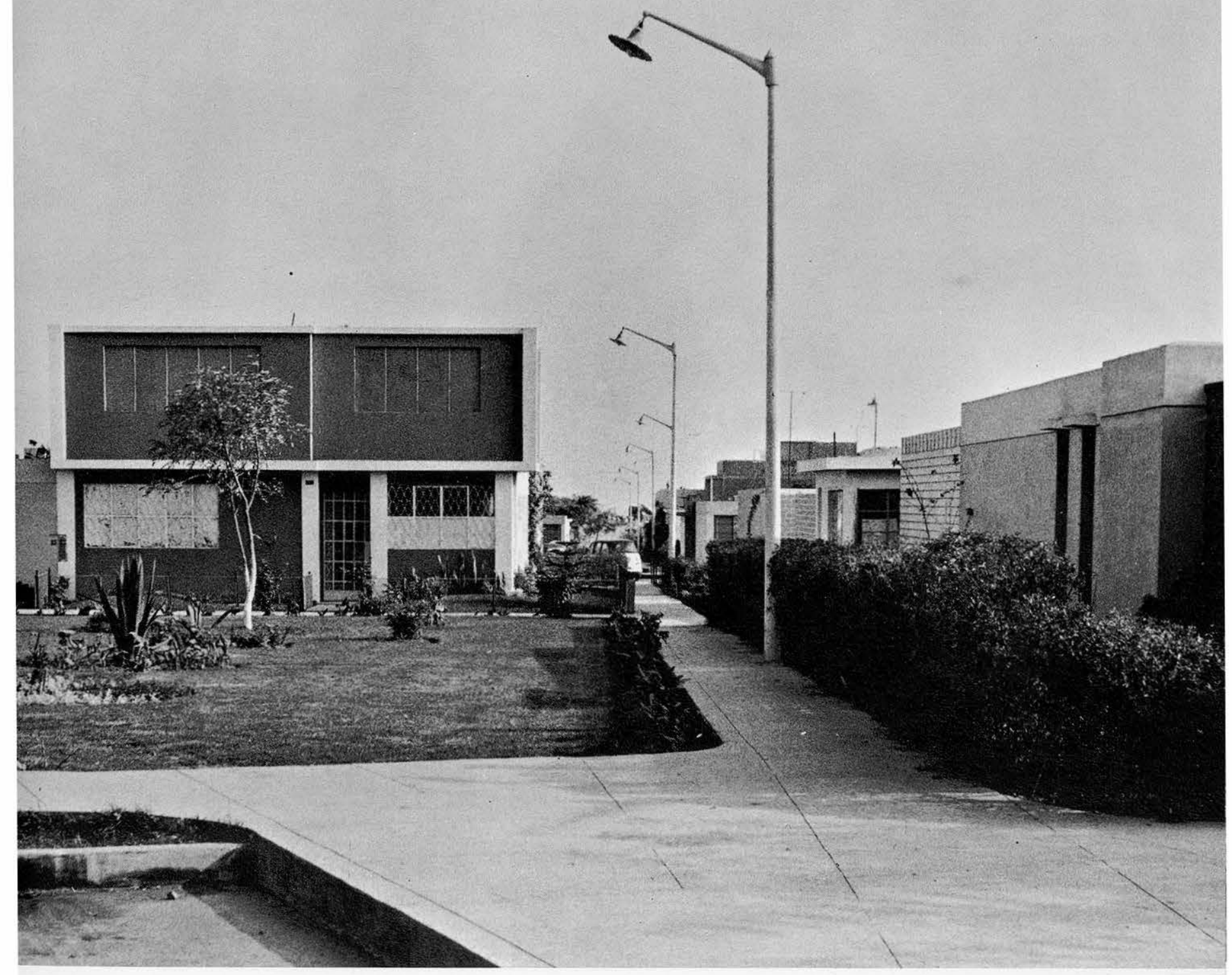

\section{nanca, Lima (50)}

is that the ability to finance construction of massive ig developments is, in most cases, dependent upon n sources.
El problema de la vivienda en Lima es similar a la que conocemos en los E.E.U.U. En los dos casos intervienen la economía, las costumbres sociales y la educación. Pero, el problema es de proporciones más serias en Lima, apesar de los recientes empeños del gobierno para tratar de aliviar la situación. La razón está en que la habilidad de financiar la construcción de inmensos proyectos de vivienda depende, en la mayoría de los casos, de recursos extranjeros. 


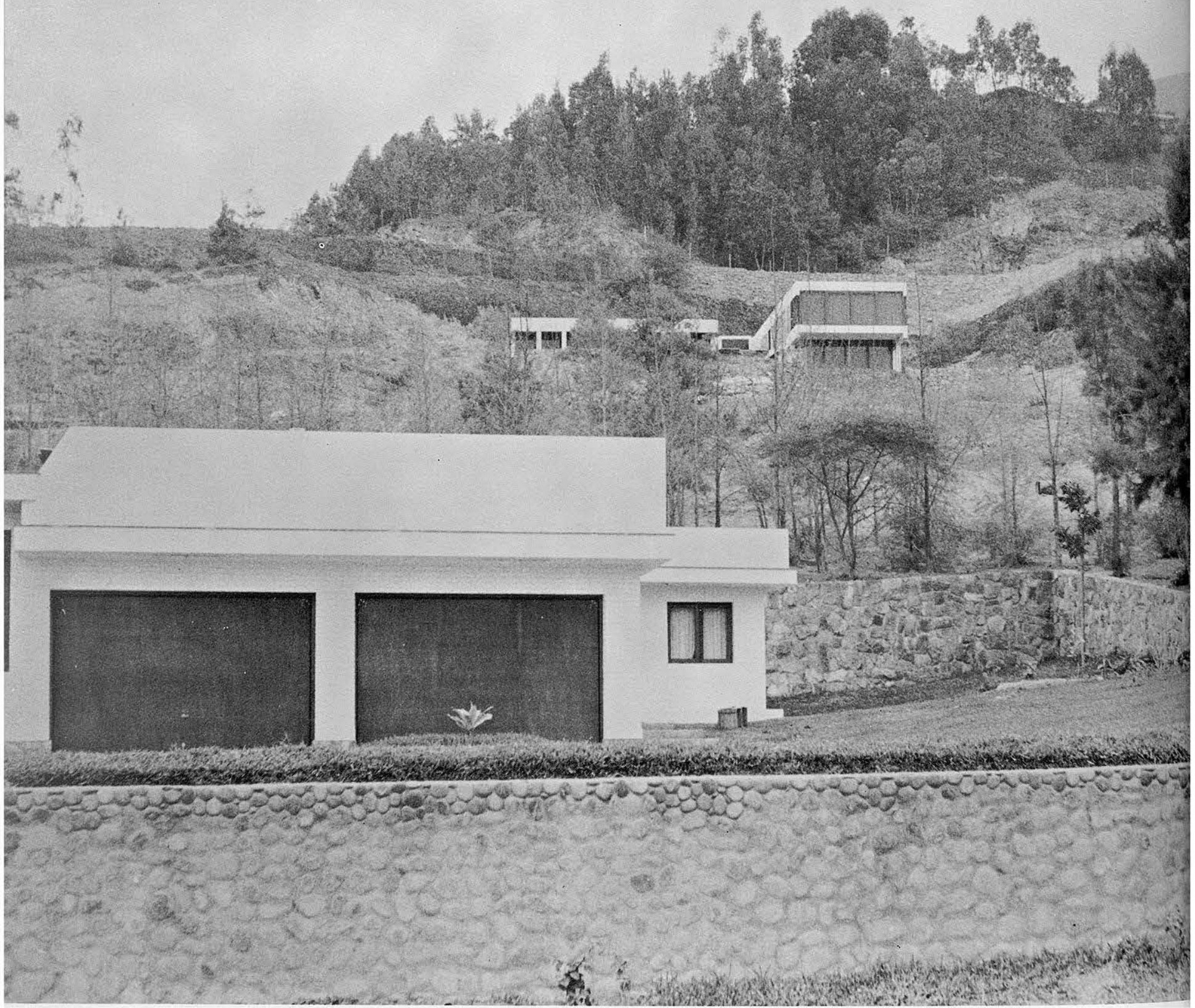

Monterrico, Lima (51)

\section{ACKNOWLEDGMENTS}

Arquitecto Carlos Morales Machiavello, Dean, Colegio de Arquitectos del Perú, whose introductions greatly facilitated this report.

Señor Antonio Olivas, Executive Secretary, Colegio de Arquitectos del Perú, who gave of his time and of the resources within the Colegio de Arquitectos to provide needed information.

Mr. Emilio Garza, Community Development Section of the
Agency for International Development (AID), Lima, for helping to obtain "barriada" information.

Arquitecto Mario Bernuy, Sectorial de Vivienda, Instituto de Planificación, for necessary information concerning construction methods, materials and financing of government projects.

Señor Carlos Peñaherrera del Aguila, Geographer, Instituto Nacional de Planificación, for climatological data. 

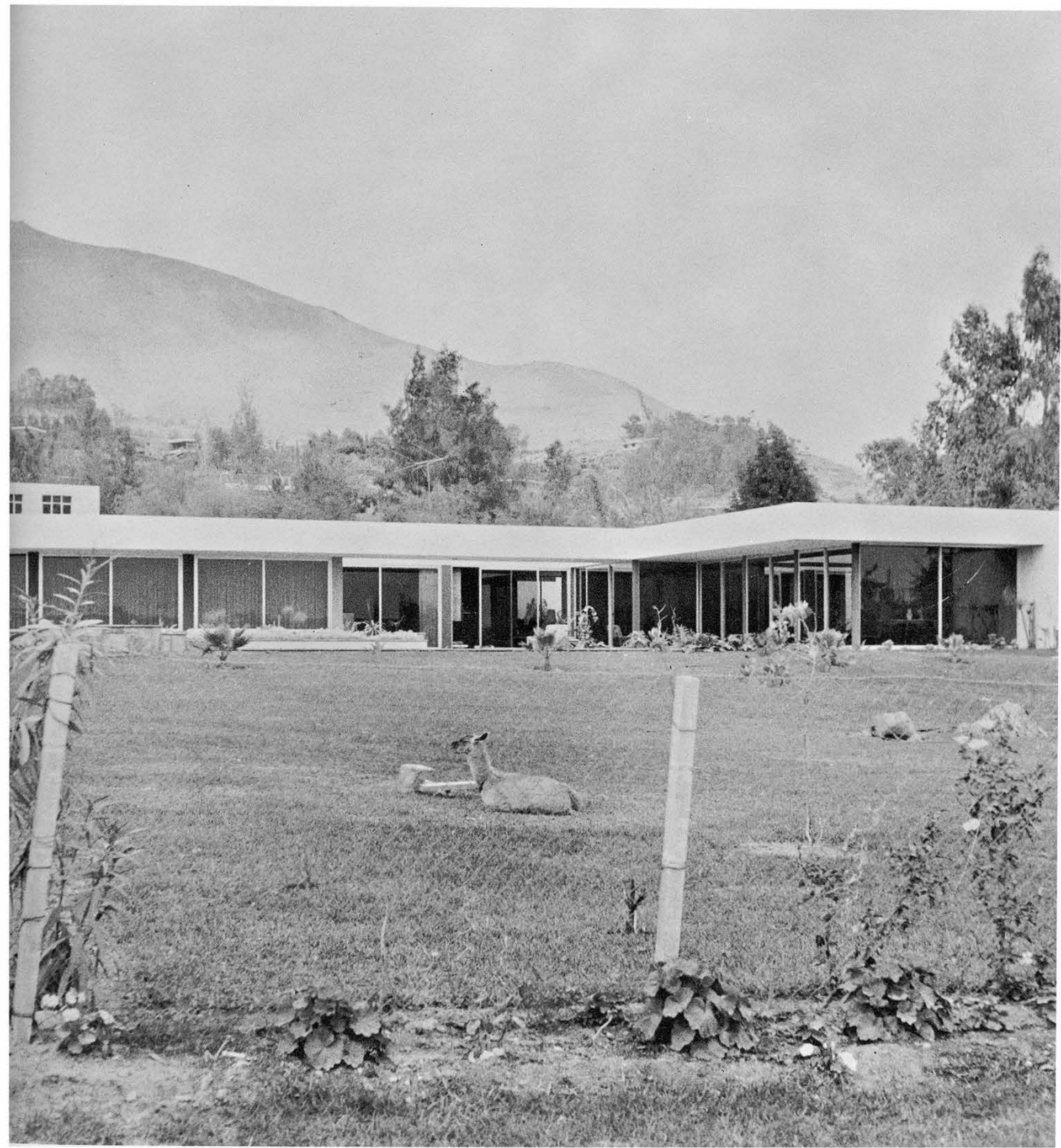

\section{Interrico, Lima (52)}

iorita Julia Zariquiex, Junta Nacional de la Vivienda, for her assistance in visiting government projects.

ior Eduardo Raygada, Housing Manager for Perú, IBEC, for information concerning IBEC.

quitecto Juán Gunther, for providing architectural information concerning IBEC.
The H. A. Speer family, for transportation, housing and helpful interest.

Mrs. Nora Speer Troy, for translations and typing of this report.

Architect Guillermo Vidaud and María Elena de la Vega de Vidaud, for additional help in translations. 


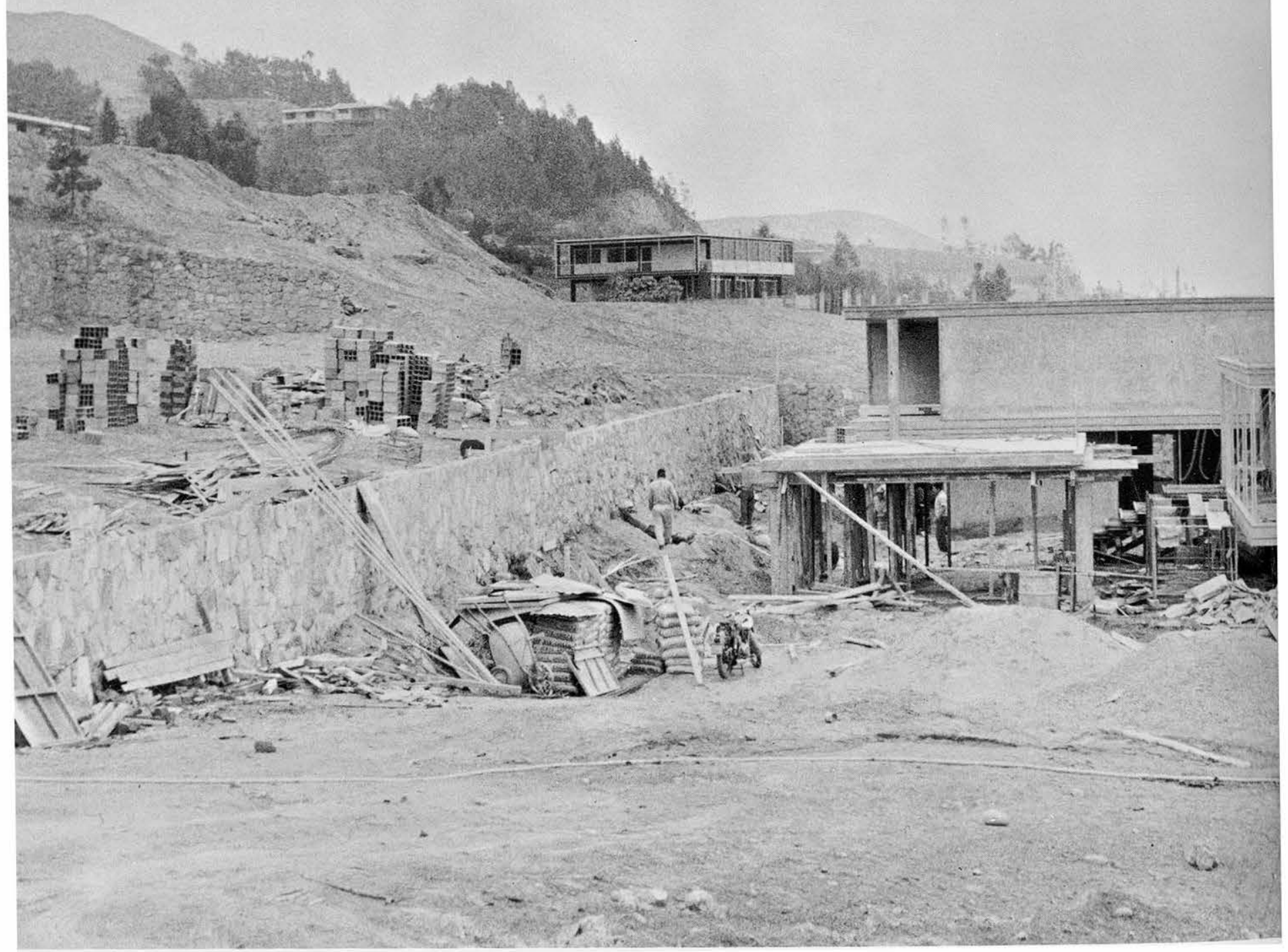

Monterrico, Lima (53)

\section{BIBLIOGRAPHY}

Velarde, Héctor, Cuarto Tomo Obras Completas de Héctor Velarde, Ensayos, Articulos Estéticos; Francisco Moncloa Editores S. A., Lima, 1966.

Comisión para la Obra de Restauración de Nuestros Monumentos Precolombinos y Virreynales, Ley 8719, Noviembre de 1938, Lima Precolombina y Virreynal; Artes Gráficas-Tipografia Peruana S. A., Lima, 1938. Centro de Investigaciones Sociales por Muestreo, Ministerio de Trabajo y Comunidades, Barriadas de Lima; Lima, 1967.

Oficina de Relaciones Públicas, Junta Nacional de la Vivienda, Obra de la Junta Nacional de la Vivienda de Julio de 1963 a Julio de 1966, Perú.

Oficina de Planificación, Sectorial de Vivienda y Equipamiento Urbano, Diagnóstico General del Problema de la Vivienda; Lima, 1966. 


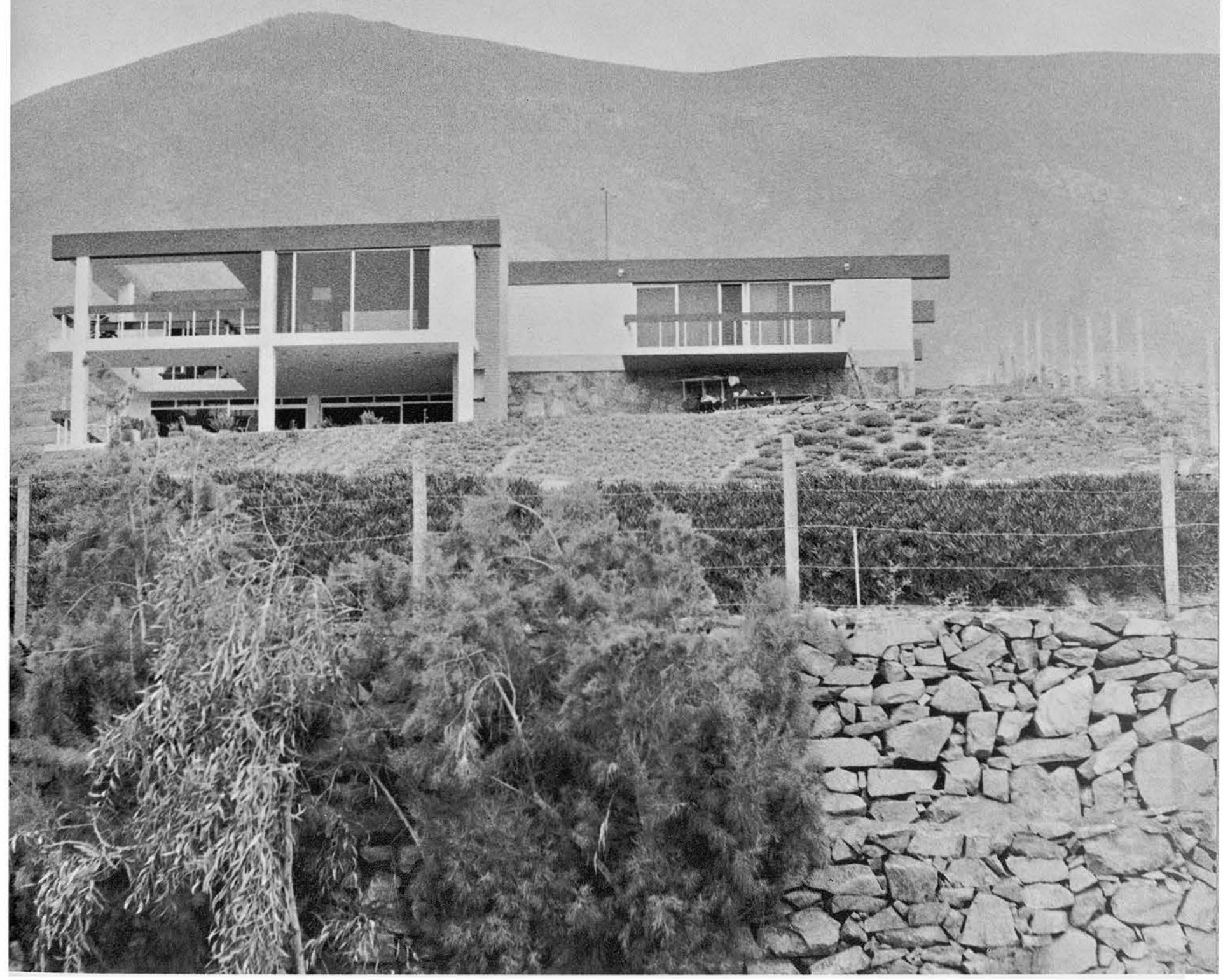

onterrico, Lima (54)

[ousing," Peruvian Times, Vol. XXVII, No. 1386; Lima, July 14, 1967, pp. 3. nferencia de Presa Ofrecida por el Arquitecto Javier
Velarde Aspillaga, Presidente del Directorio de la J.N.V., Conjuntos Residenciales San Felipe y Santa Cruz, Junta Nacional de la Vivienda; Lima, el 13 de Enero de 1967. 